\title{
ORIGENS E CONSEQUÊNCIAS DA TABELA PERIÓDICA, A MAIS CONCISA ENCICLOPÉDIA CRIADA PELO SER HUMANO
}

\author{
Geraldo M. de Limaa, ${ }^{a}$, Luiz C. A. Barbosa ${ }^{\mathrm{a}, \odot}$ e Carlos A. L. Filgueiras*,a, \\ a'Departamento de Química, Instituto de Ciências Exatas, Universidade Federal de Minas Gerais, 31270-901 Belo Horizonte - MG, \\ Brasil
}

Recebido em 06/06/2019; aceito em 05/07/2019; publicado na web em 04/11/2019

\begin{abstract}
ORIGINS AND CONSEQUENCES OF THE PERIODIC TABLE, THE MOST CONCISE ENCYCLOPEDIA CREATED BY MANKIND. The slow process of the discovery of the elements led to a need to investigate their relations with one another; this was the path, which ultimately produced Mendeleev's classification, the ancestor of the present Periodic Table. Once established, the Table, in its turn, became a guiding thread leading to the discovery of yet other new elements. This whole process can be likened to a two-way avenue, the first way leading to the establishment of the classification, whereas the latter, once established, inverted the traffic, completing our present 118-element Periodic Table. In this sesquicentennial year of its inception, it is appropriate to survey the fascinating history of the long and arduous path of the creation of what can be rightly called the most concise encyclopedia devised by the human mind.
\end{abstract}

Keywords: Periodic Table; chemical elements; Dmitri Mendeleev.

\section{INTRODUÇÃO}

O homem é um animal químico. O que quer dizer isso? Muitos animais usam instrumentos, como porretes, podem construir diques, como os castores, ou casas de barro, como os joões-de-barrro, ou ingerir folhas de plantas, para combater enfermidades.

Contudo, o homem é o único animal que domina a reação da combustão, que presidiu a origem da civilização. Por meio dela foi possível cozinhar alimentos, tornando-os mais facilmente assimiláveis, diminuindo o tempo da digestão. Todos os animais comem alimentos crus.

A combustão deu origem à metalurgia, que ampliou a capacidade humana num sem-número de atividades. Também começou aqui a saga da descoberta dos elementos.

A história da Tabela Periódica pode ser comparada a uma larga avenida de duas mãos. Num primeiro sentido, foram sendo lentamente descobertos diversos elementos químicos, pelas razões e métodos os mais distintos. Depois de se conhecerem algumas dezenas de elementos, passou-se a buscar correlações entre eles, para se entender suas peculiaridades, afinidades e reatividades. Logo se percebeu que a formulação de tais correlações poderia levar a um entendimento muito mais profundo de toda a Química. Finalmente, no início da segunda metade do século XIX, chegou-se à Tabela Periódica de Mendeleev, e sua extraordinária capacidade de prever a existência e várias propriedades de elementos desconhecidos, ainda por descobrir. Nesse ponto a avenida muda de sentido, e é agora a Tabela Periódica que vai conduzir a busca por novos elementos, de forma consistente e metódica. Dessa maneira se passou do conjunto de 63 elementos, conhecidos ao tempo de Mendeleev, aos 118 que constituem a Tabela Periódica moderna.

Quais foram os primeiros elementos descobertos?

Certamente aqueles que existem sob forma elementar na natureza: ouro, prata, às vezes cobre, carvão e enxofre, por exemplo.

Em seguida, vieram os metais que só necessitam de uma pequena intervenção química, por serem fáceis de reduzir de seus compostos naturais.

\footnotetext{
*e-mail: calfilgueiras@gmail.com
}

O homem primitivo deve ter verificado que em algumas situações as pedras colocadas para formar um suporte para sua fogueira derretiam e delas escorria um líquido prateado brilhante. Estava descoberto o princípio da metalurgia.

Um dos primeiros metais reduzidos quimicamente foi o estanho, que originaria o bronze, ao se ligar com o cobre. Se as pedras da fogueira do homem primitivo fossem de cassiterita $\left(\mathrm{SnO}_{2}\right)$, o óxido de estanho comum na natureza, em presença de carvão e com um aquecimento não muito intenso seria produzido facilmente o estanho metálico, cuja temperatura de redução é bastante baixa e cujo ponto de fusão, quando o metal escorre sob forma líquida, é de apenas $232^{\circ} \mathrm{C}$.

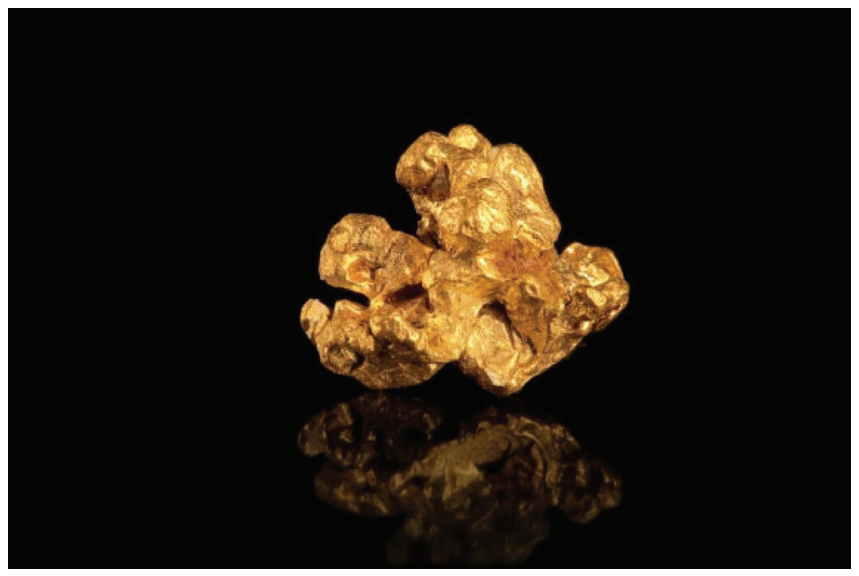

Figura 1. Pepita de ouro nativo, Museu das Minas e do Metal, Belo Horizonte

A revista Science publicou em 1982 um artigo que relata a descoberta de um recipiente de barro com mercúrio metálico de origem maia. Esse mercúrio se encontrava num achado arqueológico de D. M. Pendergast datado de antes da descoberta da América em Belize, na América Central. O mercúrio, obtido do cinábrio $(\mathrm{HgS})$, era usado em cerimônias religiosas pelos maias. A amostra data do período maia, entre $600 \mathrm{AC}$ e $900 \mathrm{AD} .^{1}$

De forma também simples se obtiveram a partir de seus minerais o cobre, o mercúrio e o chumbo. O cobre, quando não encontrado em 


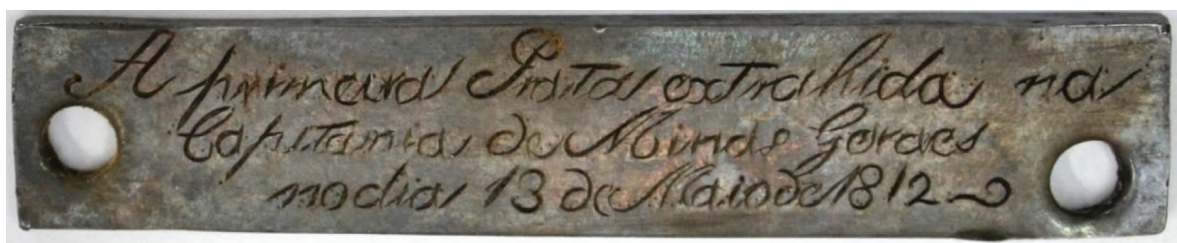

Figura 2. "A primeira Prata extrahida na Capitania de Minas Geraes no dia 18 de Maio de 1812", pelo metalurgista alemão Barão Wilhelm von Eschwege. Museu Histórico Nacional, Rio de Janeiro

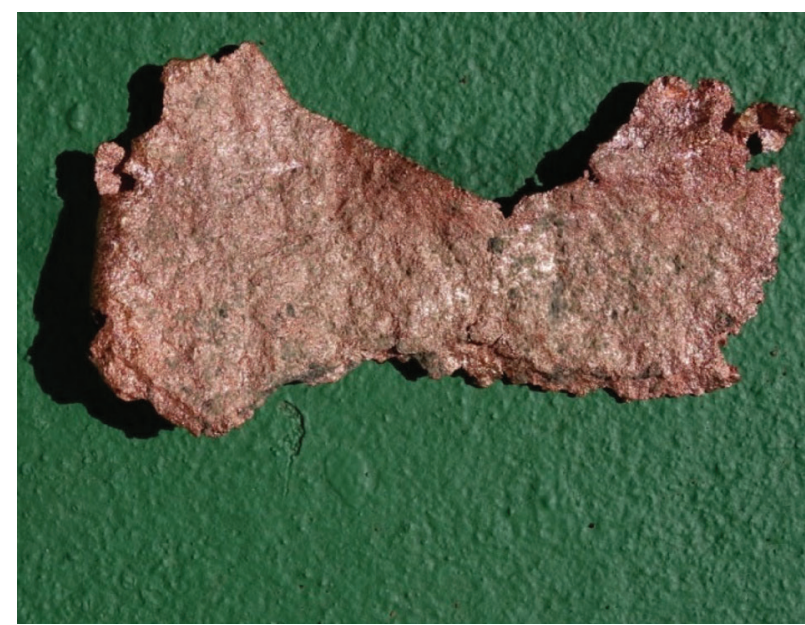

Figura 3. Amostra de cobre nativo. Coleção particular

forma elementar, como mostrado acima, podia ser obtido de vários minerais, sobretudo a malaquita, $\mathrm{Cu}_{2} \mathrm{CO}_{3}(\mathrm{OH})_{2}$. Os outros dois podiam ser facilmente reduzidos de seus sulfetos naturais, o cinábrio, $\mathrm{HgS}$, e a galena, $\mathrm{PbS}$, como já mencionado.

Dos sete metais conhecidos na Antiguidade só faltava o ferro. Esse demorou muito mais tempo para ser obtido, pois necessitava de temperaturas muito altas, já que seu ponto de fusão é de $1535^{\circ} \mathrm{C}$. Sua obtenção é atribuída aos hititas da Ásia Menor. No entanto, seu uso generalizado só ocorreu muito mais tarde, variando conforme as diferentes culturas.
Uma das peças mais interessantes encontrada na tumba do faraó egípcio Tutancâmon, morto em 1324 AC, foi uma adaga em ferro. Todavia ela foi feita de ferro meteorítico, uma vez que naquela data os egípcios ainda não dominavam a metalurgia do ferro. O interessante é que a lâmina não se tenha corroído após 33 séculos, possivelmente pela presença de níquel. ${ }^{2}$

O aparecimento da metalurgia do ferro em torno de 1300-1200 A.C. acabou por dar fim à Idade do Bronze. Esse imenso salto tecnológico é atribuído aos hititas, um povo relativamente pouco conhecido, cuja civilização floresceu na Anatólia. Os minerais magnetita $\left(\mathrm{Fe}_{3} \mathrm{O}_{4}\right)$ e olivina $\left[(\mathrm{Mg}, \mathrm{Fe})_{2} \mathrm{SiO}_{4}\right]$, encontrados na costa sul do Mar Negro, permitem a redução do ferro à temperatura relativamente branda de $900{ }^{\circ} \mathrm{C}$. O ferro esponjoso que se obtém precisa ser reaquecido e repetidamente martelado sobre o fogo para eliminar a escória. Durante esse processo forma-se um produto muito mais duro que o ferro puro. Este produto é o aço, que é um ferro com baixo teor de carbono. ${ }^{3}$

Durante a Idade Média, e até além dela, conheciam-se apenas os sete metais herdados da Antiguidade. A partir do Renascimento, contudo, a situação começou a mudar.

Uma obra importante neste aspecto é o livro Aula Subterranea, do alemão Lazarus Ercker (1528/30-1594), cuja primeira edição data do século XVI. A Figura 5 mostra o frontispício da edição de 1673, no qual está representado alegoricamente como Deus envia por raios solares os metais às entranhas das montanhas, de onde os homens extraem os minérios e deles obtêm os metais

A exploração de novos continentes a partir do século XVI levou à intensa atividade manufatureira na Europa. Para a tarefa de colonização era necessária uma gigantesca produção dos bens mais diversos possíveis.
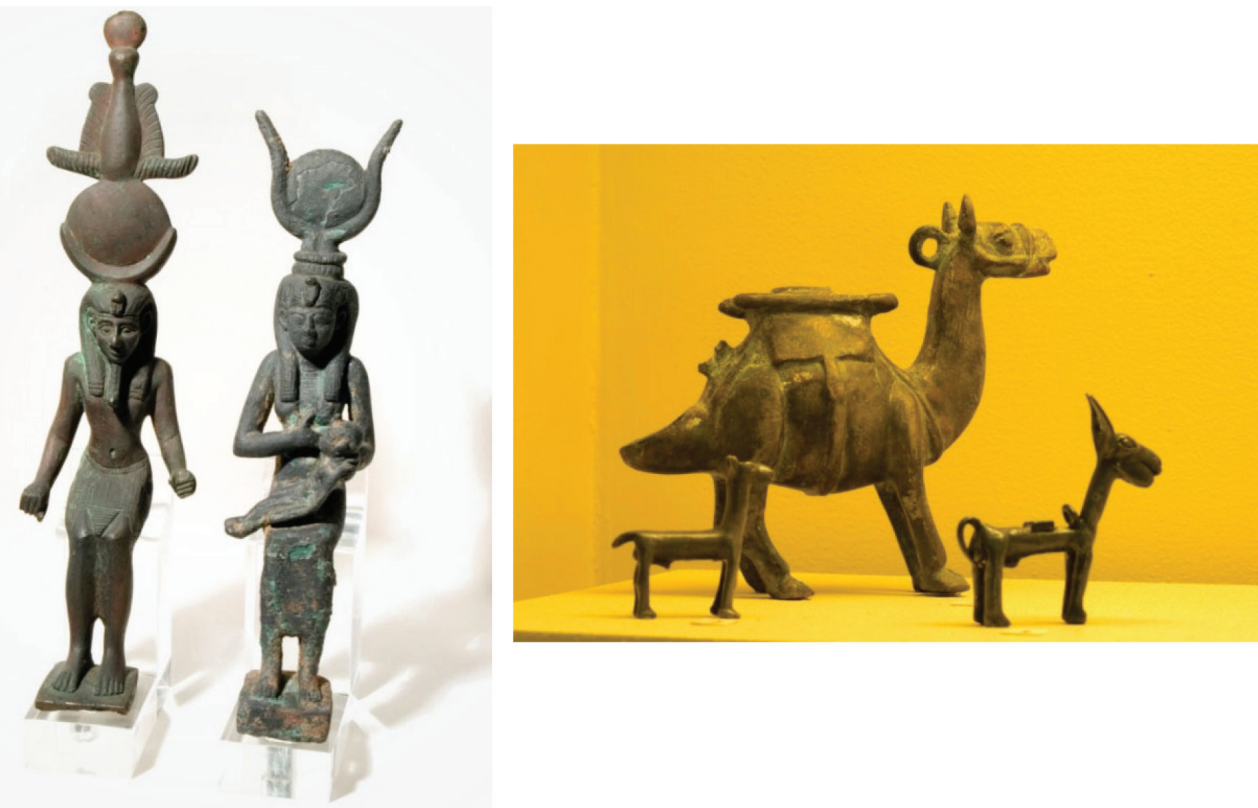

Figura 4. Bronzes antigos das coleções do Museu Nacional, em fotos de antes do incêndio de 2 de setembro de 2018: (A) conjunto egípcio com os deuses Osíris e Ísis, essa amamentando o infante Hórus; (B) família de lhamas da cultura inca. O bronze, uma liga de cobre e estanho em proporções variadas, é uma liga muito mais dura e resistente que qualquer dos metais componentes. Ele foi descoberto independentemente em várias culturas e deu origem a uma era da evolução cultural da humanidade 


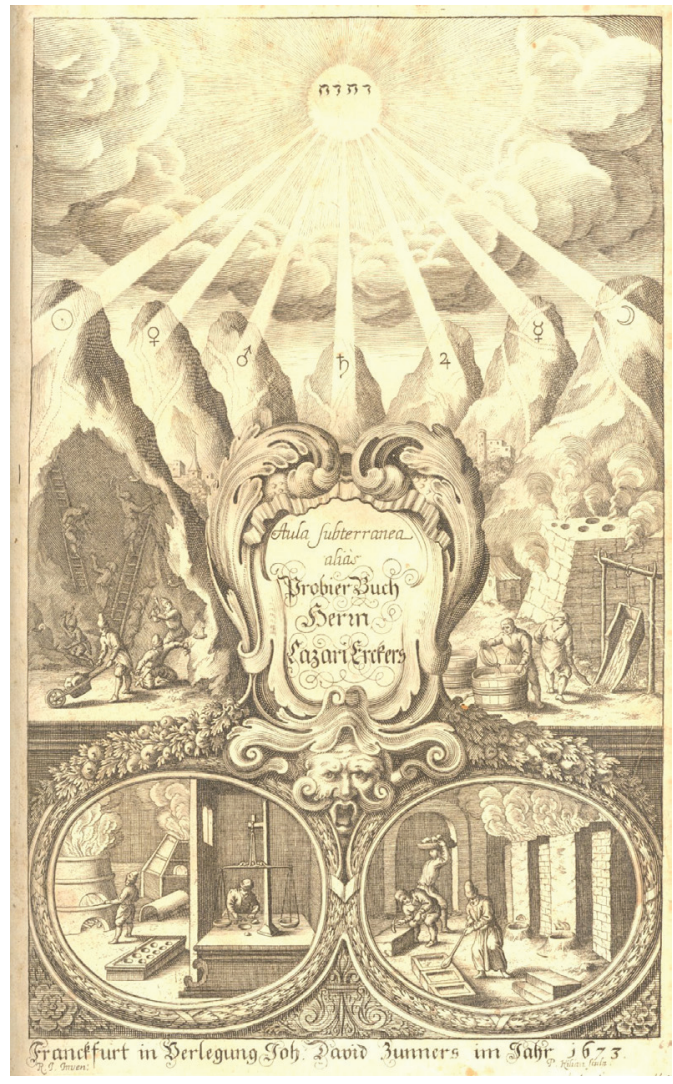

Figura 5. Frontispício da segunda edição do livro Aula Subterranea, de Lazarus Ercker, de 1673. Aqui está mostrado alegoricamente como Deus envia por raios solares os metais às entranhas das montanhas, de onde os homens extraem os minérios e deles obtêm os metais ${ }^{4}$

Entre esses bens havia demanda por metais e instrumentos, máquinas, armas, objetos de cerâmica, como telhas, tijolos, vasos e todo tipo de recipiente, papel em quantidades gigantescas, vidro e objetos feitos com ele, pigmentos e tinturas, tecidos, couros e materiais para curtume, medicamentos, etc.

Começou-se a produzir esses materiais e objetos nas colônias, mas o fornecimento pela Europa também cresceu exponencialmente. Isso conduziu a incremento significativo na produção de manufaturas, num processo pré-industrial de grande envergadura.

A partir daí começou-se a descobrir vários novos elementos, metálicos ou não.

Compostos de arsênio e antimônio já eram comuns no século XVI. O trióxido de arsênio - um veneno conhecido como arsênico - tem história folclórica, com nome popular de pó da sucessão, pois era usado por herdeiros em bolos ou vinhos presenteados a antecessores abastados.

Johannes Gutenberg (1400-1468) em 1454 usou tipos móveis de impressão feitos com liga de antimônio, estanho e chumbo, em sua pioneira tipografia com tipos móveis na cidade de Mogúncia. Gutenberg e seus colaboradores costumam ser apontados como os originadores de uma revolução na difusão do conhecimento, tão importante em seu tempo como a Internet a partir do final do século XX. Antes da invenção dos tipos móveis os livros eram escritos ou copiados a mão, mas a partir de meados do século XV eles podiam ser produzidos em larga escala. Esta digressão no presente texto tem a ver com o fato de que em meados do século XV já se produzia com facilidade a liga dos três metais - antimônio, estanho e chumbo - usados nos tipos de impressão, o primeiro deles desconhecido na Antiguidade. A liga formada por eles era de baixo ponto de fusão e suportava os esforços mecânicos inerentes à arte do tipógrafo. A
Biblioteca Nacional do Rio de Janeiro possui uma edição preciosa, em dois volumes, de uma Bíblia impressa pelos sócios de Gutenberg em Mogúncia Johann Fust (1400-1466) e Peter Schöffer (1425-1503) em 1462. Essa Bíblia é o livro impresso mais antigo do Brasil. Como além de representar um marco na história da cultura, essa obra também demonstra o avanço na descoberta e utilização de novos metais, ela está aqui mostrada, na Figura 6.

Compostos de antimônio eram usados como medicamentos, e muito louvados como tal. Um livro com muitas edições no séc. XVII foi A Carruagem Triunfal do Antimônio, de autoria incerta. ${ }^{6} \mathrm{~A}$ manteiga de antimônio, ou tricloreto de antimônio, foi medicamento muito usado no Brasil colonial, como purgante.?

O bismuto é mencionado desde o século XV. Por volta de 1669 o alquimista alemão Hennig Brand (c. 1730 - c. 1692 ou c. 1710) obteve, a partir de grandes quantidades de urina, o elemento fósforo, que emite luz espontaneamente no escuro, no processo de transição do alótropo branco (fosforescente) para a forma vermelha, mais estável. ${ }^{8}$ A descoberta do fósforo, contudo, foi cercada de muitos relatos conflitantes.

Ao longo do século XVIII descobriu-se que o ar atmosférico não era elementar, e sim uma mistura de "ares", ou gases. Foram descobertos sucessivamente o gás carbônico, o hidrogênio, o nitrogênio e o oxigênio, além de outros gases compostos, como o óxido nítrico.

A química do século XVIII foi essencialmente uma química pneumática, ou dos gases.

O número de novos elementos cresceu bastante e em 1789, em seu Tratado Elementar de Química (Figura 7), Antoine-Laurent Lavoisier (1743-1794) (Figura 8) listou 33 elementos, numa tentativa de classificá-los, embora dois de seus "elementos", a luz e o "calórico", fossem depois descartados como tais.

Entre os metais, Lavoisier acrescentou aos sete conhecidos desde a antiguidade o bismuto, o cobalto, o manganês, o molibdênio, o níquel, a platina, o tungstênio e o zinco. Acrescentou ainda substâncias que ele suspeitava contivessem metais, como os óxidos denominados cal, magnésia, barita, alumina e sílica.

Na tabela de Lavoisier, dois itens não são reconhecidos hoje como elementos (a luz e o calórico), três eram chamados por ele de "radicais" (muriático, fluórico e borácico), os quais ele supunha acertadamente que contivessem elementos ainda não isolados, e cinco eram denominados "bases" (cal, magnésia, barita, argila, sílica), que também deviam conter, segundo Lavoisier, elementos ainda não isolados na época.

Na tabela de Lavoisier, ou "Tabela das Substâncias Simples", que poderia ser chamada uma "pré-história" da Tabela Periódica, vê-se uma classificação de elementos em quatro grupos. Desses 33 "elementos", não reconhecemos, como já dito, a luz e o suposto "calórico" como elementos, restando 31. Dos 31, 23 eram conhecidos na forma elementar, e para os outros oito Lavoisier presumia sua existência em substâncias conhecidas, como ele descreveu em seu livro. Aqui estão os quatro grupos de elementos, segundo o químico francês:

Grupo 1: contém cinco elementos, "substâncias simples que pertencem aos três reinos e que podem ser vistos como elementos nos corpos". Estes 5 elementos são: luz, calórico, oxigênio, azoto e hidrogênio.

Grupo 2: contém seis elementos, definidos como "substâncias simples não-metálicas oxidáveis e acidificáveis”. São eles: enxofre, fósforo, carbono, radical muriático, radical fluórico e radical borácico.

Grupo 3: este é o maior grupo, constando de 17 elementos, chamados "substâncias simples metálicas oxidáveis e acidificáveis": antimônio, prata, arsênio, bismuto, cobalto, cobre, estanho, ferro, manganês, mercúrio, molibdênio, níquel, ouro, platina, chumbo, tungstênio e zinco.

Grupo 4: este grupo, consta de cinco "elementos", nenhum dos quais propriamente elementar, como o próprio Lavoisier declara no 

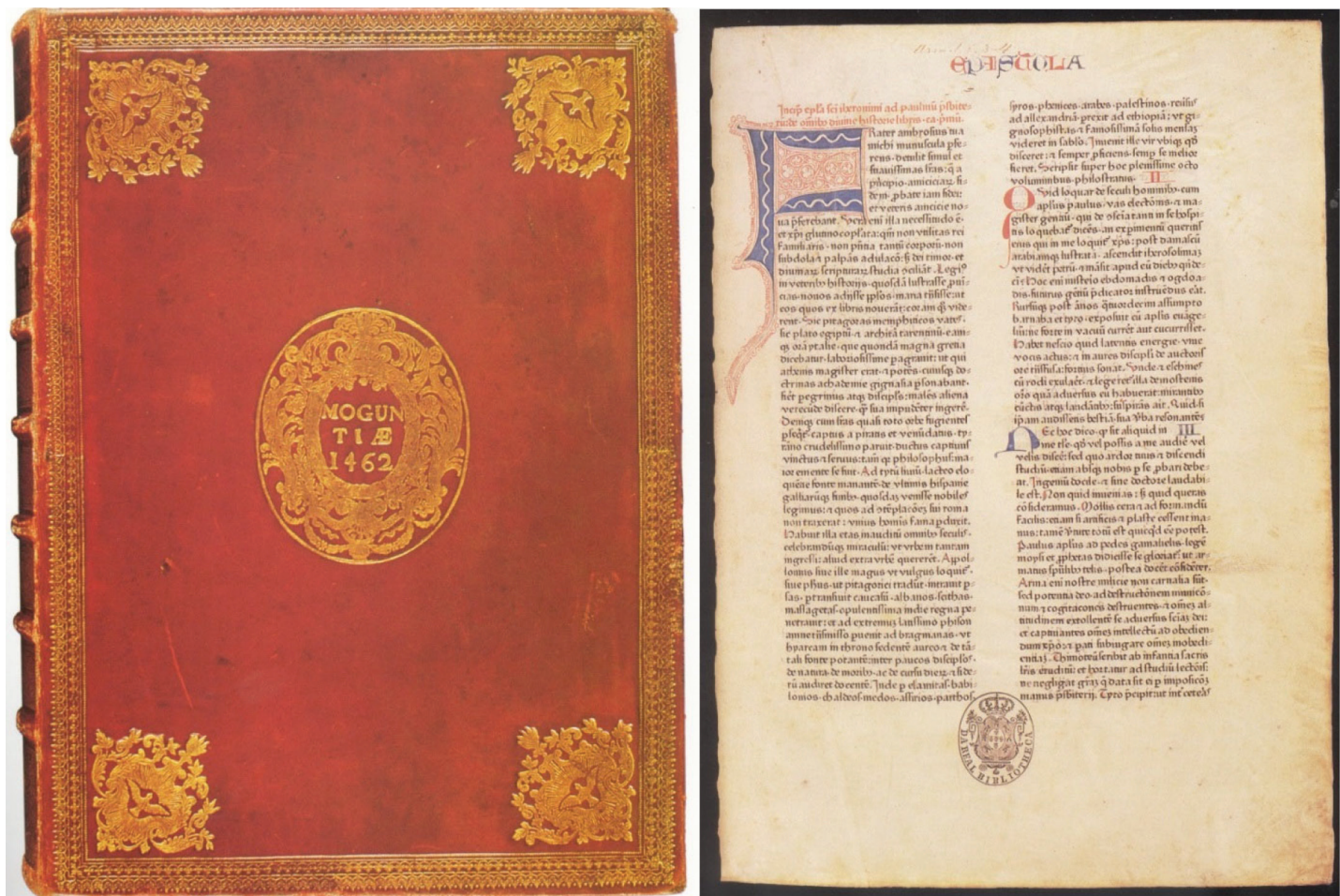

Figura 6. O livro impresso mais antigo existente no Brasil, a Bíblia de Mogúncia, impressa em dois volumes nessa cidade alemã em 1462, usando tipos móveis de liga metálica de Sb, Sn e Pb. As fotos mostram a capa do primeiro volume e uma página com inicial desenhada. Fundação Biblioteca Nacional ${ }^{5}$

192 DES SUBSTANCES SIMPLES.

TABLEAU DES SUBSTANCES SIMPLES.

\begin{tabular}{|c|c|c|}
\hline & Notns nouveaux. & Noms anciens correfpondans. \\
\hline $\begin{array}{l}\text { Sutftances fim- } \\
\text { ples qui appar- } \\
\text { tiennent aux } \\
\text { trois règnes \& } \\
\text { qu'on peut regar- } \\
\text { der comine les } \\
\text { élément des } \\
\text { corps. }\end{array}$ & 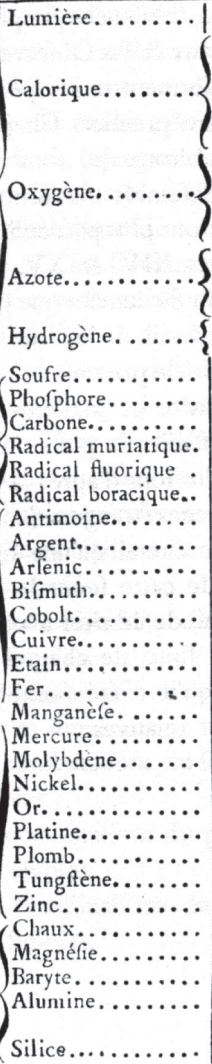 & $\begin{array}{l}\text { Lumière. } \\
\text { Chaleur. } \\
\text { Principe de la chaleur. } \\
\text { Fluide igné. } \\
\text { Feu. } \\
\text { Maticre du feu \& de la chaleur. } \\
\text { Air déphlogiftiqué. } \\
\text { Air empiréal. } \\
\text { Air vital. } \\
\text { Bafe de l'air vital. } \\
\text { Gaz phlogiftiqué. } \\
\text { Mofete. } \\
\text { Bafe de la mofete. } \\
\text { Gaz infiammable. } \\
\text { Bafe du gaz inflammable. } \\
\text { Soufre. } \\
\text { Phofphore. } \\
\text { Charbon pur. } \\
\text { Inconnu. } \\
\text { Inconnu. } \\
\text { Inconnu. } \\
\text { Antimoine. } \\
\text { Argent. } \\
\text { Arienic. } \\
\text { Bifmutl. } \\
\text { Cobolt. } \\
\text { Cuivre. } \\
\text { Etain. } \\
\text { Fer. } \\
\text { Manganèfe. } \\
\text { Mercure. } \\
\text { Molybdène. } \\
\text { Nickel. } \\
\text { Or. } \\
\text { Platine. } \\
\text { Plomb. } \\
\text { Tungftène. } \\
\text { Zinc. } \\
\text { Terre calcaire, chaux. } \\
\text { Magnéfie, bafe du fel d'Epfem. } \\
\text { Barote, terre pefante. } \\
\text { Argile, terre de l'alun, bafe } \\
\text { de l'alun. } \\
\text { Terrefiliceufe, terre vitrifiable. }\end{array}$ \\
\hline
\end{tabular}

Figura 7. A Tabela dos 33 elementos de Lavoisier, publicada em seu livro principal, Traité Élémentaire de Chimie, de $1789^{9}$

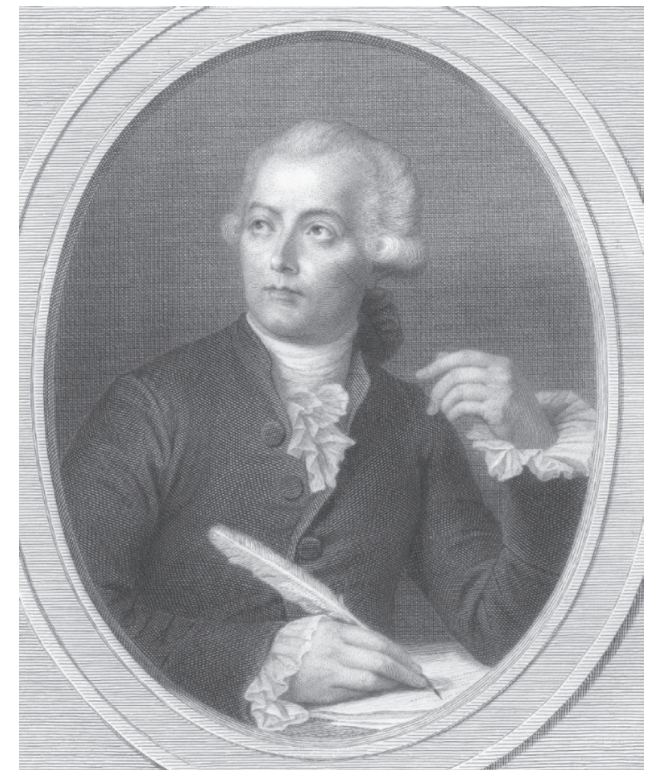

Figura 8. Retrato de Lavoisier, desenhado por Jacques-Louis David e gravado por sua mulher Marie-Anne Pierrette Paulze Lavoisier. Oeuvres de Lavoisier, Imprimerie Impériale, Paris, tome premier, $1864^{10}$

texto. Estes cinco membros são descritos como "substâncias simples salificáveis": cal, magnésia, barita, alumina e sílica. Lavoisier estava correto em supor a existência de verdadeiros elementos nessas substâncias, assim como havia presumido quanto aos três radicais do grupo 2.

No século XVIII descobriram-se novos metais: tungstênio, molibdênio, urânio, cromo, telúrio e selênio. Destes, só os dois primeiros constam da tabela de Lavoisier.

Diversos elementos foram descobertos na Europa Oriental, região tradicionalmente importante no progresso da mineralogia e da metalurgia. 
Os elementos nióbio, tântalo e vanádio foram descobertos no início do século XIX, embora sua redução à forma elementar tenha levado mais tempo.

Não se buscará aqui fazer uma discussão exaustiva da descoberta de todos os elementos químicos, uma vez que o objetivo deste artigo não é esse, mas sim mostrar como o acúmulo de elementos descobertos levou a uma necessidade classificatória que acabou dando origem à Tabela Periódica, e esta, por sua vez, veio a conduzir a mais descobertas de elementos. Todavia, a descoberta de alguns elementos será descrita, como ilustração, ou por alguns aspectos peculiares de interesse na evolução do conhecimento químico nesse aspecto. Para uma descrição exaustiva e abrangente da descoberta dos elementos químicos, recomenda-se ao leitor interessado consultar a obra citada na referência 8.

O vanádio foi o primeiro elemento descoberto no Novo Mundo, pelo mineralogista espanhol Andrés Manuel del Río y Fernández (1764-1849), professor de mineralogia no Real Seminario de Minería da Cidade do México. Em razão do pioneirismo de del Río é interessante mencionar as circunstâncias da descoberta. Andrés del Río nasceu em Madrid e estudou na Espanha e em vários países europeus. Em 1794 foi nomeado professor de mineralogia na Cidade do México, então capital da Nova Espanha, e lá desenvolveu longa e frutuosa carreira. Em 1801, ao examinar uma amostra de chumbo marrom de Zimapán (plomo pardo de Zimapán), del Río mostrou que ela continha um novo metal semelhante ao cromo e ao urânio. Os sais desse metal apresentavam cores variadas, por isso ele o chamou inicialmente panchromium, mas depois, ao perceber que seus sais com álcalis ou terras ficavam vermelhos por aquecimento ou tratamento com ácidos, mudou o nome para erythronium, por causa da cor vermelha, eritros em grego. Em 1803 del Río deu a Alexander von Humboldt (1769-1859) várias amostras do mineral, que este enviou ao Institut de France. Todavia, uma descrição detalhada do novo metal, enviada ao químico francês Jean Antoine Chaptal (1756-1832), perdeu-se num naufrágio.

Na Europa fazia-se grande confusão entre o metal descoberto por del Río, de personalidade muito modesta, e um outro metal novo, o cromo. Por isso, acabou-se por relegar a descoberta de del Río a uma simples descrição de um mineral de cromo. Só em 1831 o químico sueco Nils Gabriel Sefström (1787-1845) voltou ao assunto, analisando um mineral de ferro de uma mina sueca. Ele conseguiu provar decididamente que se tratava de um novo metal e deu-lhe o nome da deusa nórdica da beleza Vanadis, em decorrência das belas cores das soluções dos sais de vanádio. É por isso que o nome oficial do metal é vanádio. ${ }^{11}$

Em 1800 Alessandro Volta inventou a pilha elétrica, possibilitando assim enorme passo rumo à descoberta e isolamento de muitos novos elementos. Nesta conta estão, por exemplo, os metais alcalinos e alcalinoterrosos, isolados por via eletroquímica a partir de seus sais fundidos, em ausência de água, nos primeiros anos do século XIX.

Também neste período foram descobertos vários metais nobres, completando o grupo da platina: platina, ródio, ósmio, irídio, paládio e rutênio.

A obtenção do sódio e do potássio permitiu seu uso na redução de metais. A dificuldade em obter certas substâncias elementares por meios convencionais foi vencida usando metais alcalinos como redutores. Assim foram isolados: zircônio, titânio, cério, tório, berílio, boro, silício e alumínio.

Os três primeiros halogênios descobertos também o foram no início do século XIX, época fértil neste campo.

Em 1774 Carl Scheele (1742-1786) obtivera um gás verde pela ação de $\mathrm{HCl}$ aquoso sobre $\mathrm{MnO}_{2}$, mas não reconheceu seu caráter elementar. ${ }^{12}$ Isso só ocorreu em 1810, quando Humphry Davy (1778-1829) mostrou a natureza elementar do cloro. No ano seguinte
Bernard Courtois (1777-1838) isolou o iodo das cinzas de algas marinhas. Logo foi obtido o bromo, e começou-se a pensar na existência de uma relação entre esses três elementos, com propriedades semelhantes. O flúor demorou muito a ser obtido, só em 1886, por Henri Moissan (1852-1907), usando a eletroquímica.

\section{A ESPECTROSCOPIA ATÔMICA E A DESCOBERTA DE NOVOS ELEMENTOS}

Em 1859 um trabalho conjunto do químico Robert Bunsen (1811-1899) e do físico Gustav Kirchhoff (1824-1887), ambos da Universidade de Heidelberg, levou a um novo patamar os estudos dos elementos e seus compostos, a espectroscopia atômica. Todos nós já vimos que quando um alimento na panela entorna, o fogo do gás fica amarelo (desde que se trate de alimento com sal), porque o sódio, ao ser excitado em alta temperatura emite luz, cujo comprimento de onda é característico. Isso ocorre com todos os elementos, e este é o princípio da espectroscopia de emissão. O que Bunsen e Kirchhoff descobriram foi que, ao passar a luz emitida por um elemento através de um prisma de cristal e depois incidi-la sobre um anteparo, o resultado é o aparecimento de várias raias coloridas, em comprimentos de onda muito bem definidos. Essas raias são uma impressão digital de cada elemento e permitem identificar quais estão contidos numa amostra excitada, que emita luz. Assim procedendo, eles logo descobriram, em águas minerais, dois novos elementos, o rubídio e o césio. Os nomes vêm justamente das cores produzidas no espectro, vermelho como o rubi (daí o nome rubídio) e azul para o césio (do latim caesius, ou azul celeste). Pouco depois também foram assim descobertos o tálio e o índio. A espectroscopia logo se mostrou uma técnica analítica poderosíssima, pois permitiu fazer até a análise química de estrelas distantes, por meio do estudo espectroscópico da luz emitida por elas. ${ }^{13}$

A partir da análise da radiação da coroa solar observada quando do eclipse total do sol de 1868, Pierre Jules César Janssen (1824-1907) na França e Joseph Norman Lockyer (1836-1920) na Inglaterra, descobriram independentemente uma nova linha amarela, desconhecida para qualquer elemento existente na Terra. Isso causou grande sensação e eles deram a este novo elemento o nome do deus grego do sol, Hélio. É claro que uma descoberta dessa natureza gerou muita controvérsia, e muitos cientistas na época recusaram-se a aceitar a existência do novo elemento, para o qual não havia um nicho na Tabela Periódica, que veio a ser proposta quase ao mesmo tempo, em 1869.14

Só 27 anos depois, em 1895, foi o hélio descoberto na Terra, em minerais radioativos, por William Ramsay (1852-1916) na Inglaterra e Per Teodor Cleve (1840-1905) e Nils Abraham Langlet (1868-1936) na Suécia, independentemente. A controvérsia sobre a análise do espectro solar foi então terminada e a espectroscopia vindicada. ${ }^{14}$

\section{O SURGIMENTO DA TABELA PERIÓDICA}

Muitas descobertas científicas necessitam de um tempo de gestação, surgindo apenas quando o conhecimento está maduro para seu aparecimento. Isso ocorreu com a Tabela Periódica. Foi preciso um acúmulo considerável de elementos conhecidos para que se pudessem descobrir relações entre eles e para que fosse possível ordená-los de modo racional e útil. Uma vez feito esse ordenamento, este, por sua vez, pôde levar a previsões e consequente busca por novos elementos, fenômeno de enorme interesse que foi uma consequência direta do surgimento da Tabela Periódica.

A partir da segunda década do século XIX começaram a surgir tentativas de relacionar os elementos químicos a partir de suas propriedades. Uma dessas tentativas se deveu ao químico alemão Johann Wolfgang Döbereiner (1782-1849), ao perceber, em 1816, que o 
peso atômico do estrôncio, 50, era a média aproximada dos pesos atômicos do cálcio e do bário, e o mesmo ocorria com a gravidade específica (para o que hoje se diria densidade) dos sulfatos desses três elementos. ${ }^{15}$ Sua ideia de tríades só surgiu de fato em 1829 , após a publicação dos pesos atômicos mais acurados de Jöns Jacob Berzelius (1779-1848). Döbereiner pôde então mostrar para vários conjuntos de três elementos (suas tríades) que o peso atômico do elemento do meio era aproximadamente a média dos pesos atômicos dos outros dois membros da tríade. Entre suas tríades, contam-se:

$\begin{array}{lllll}\text { lítio } & \text { cálcio } & \text { cloro } & \text { enxofre } & \text { manganês } \\ \text { sódio } & \text { estrôncio } & \text { bromo } & \text { selênio } & \text { cromo } \\ \text { potássio } & \text { bário } & \text { iodo } & \text { telúrio } & \text { ferro }\end{array}$

Döbereiner também fez algumas suposições arbitrárias, ao desconsiderar o magnésio, como sendo um elemento isolado, e o flúor, que mesmo não tendo sido ainda isolado, era conhecido em compostos. Ele também desconsiderou o conjunto formado por carbono, nitrogênio e oxigênio, mesmo com o peso atômico do nitrogênio sendo a média dos pesos atômicos dos outros dois, pelo fato de eles não serem metais. ${ }^{15}$

Várias outras ideias foram surgindo ao longo do século XIX. O químico francês Jean-Baptiste Dumas (1800-1884) propôs em 1859 uma conexão curiosa entre os pesos de uma sucessão de grupos orgânicos homólogos e séries de elementos. Aqui estão alguns de seus exemplos:

$\mathrm{H}=1+(0 \times 14)$

$\mathrm{CH}_{3}=1+(1 \times 14)$

$\mathrm{C}_{2} \mathrm{H}_{5}=1+(2 \times 14)$

$\mathrm{C}_{3} \mathrm{H}_{7}=1+(3 \times 14)$

$\mathrm{C}_{4} \mathrm{H}_{9}=1+(4 \times 14)$

$\mathrm{F}=19=19$

$\mathrm{Cl}=19+16,5=35,5$

$\mathrm{Br}=19+(2 \times 16,5)+28=80$

$\mathrm{I}=19+(2 \times 16,5)+(2 \times 19)+19=127$

$\mathrm{O}=8=8$

$\mathrm{S}=8+8=16$

$\mathrm{Se}=8+(4 \times 8)=40$

$\mathrm{Te}=8+(7 \times 8)=64$

Dumas apresentou vários outros conjuntos semelhantes e chegou a especular se isto não seria afinal uma indicação de que o velho sonho dos alquimistas, da transmutação de um elemento em outro, não poderia ocorrer? O peso atômico do selênio correspondia à média daquele do enxofre e do telúrio; algo semelhante ocorria entre cloro, bromo e iodo. Todavia, nem sempre era assim, de modo que a especulação de Dumas não prosperou. ${ }^{16}$

O geólogo e mineralogista francês Alexandre Émile Béguyer de Chancourtois (1820-1886) organizou os elementos em 1862, segundo seus pesos atômicos crescentes, na superfície de um cilindro em que os elementos ocupavam uma linha que formava uma hélice com um ângulo de $45^{\circ}$ em 16 seções. Seu esquema, embora ainda um pouco primitivo, passou a ser conhecido como cilindro ou parafuso telúrico (vis tellurique, em que vis é parafuso em francês, e telus é a Terra em latim) (Figura 9). O trabalho de de Chancourtois não se tornou conhecido dos químicos em geral por ele ser um geólogo e o ter publicado num contexto geológico.

\section{LEI DAS OITAVAS DE NEWLANDS}

O inglês John Alexander Reina Newlands (1837-1898), bastante
ESQUISSE DE LA VIS TELLURIQUE

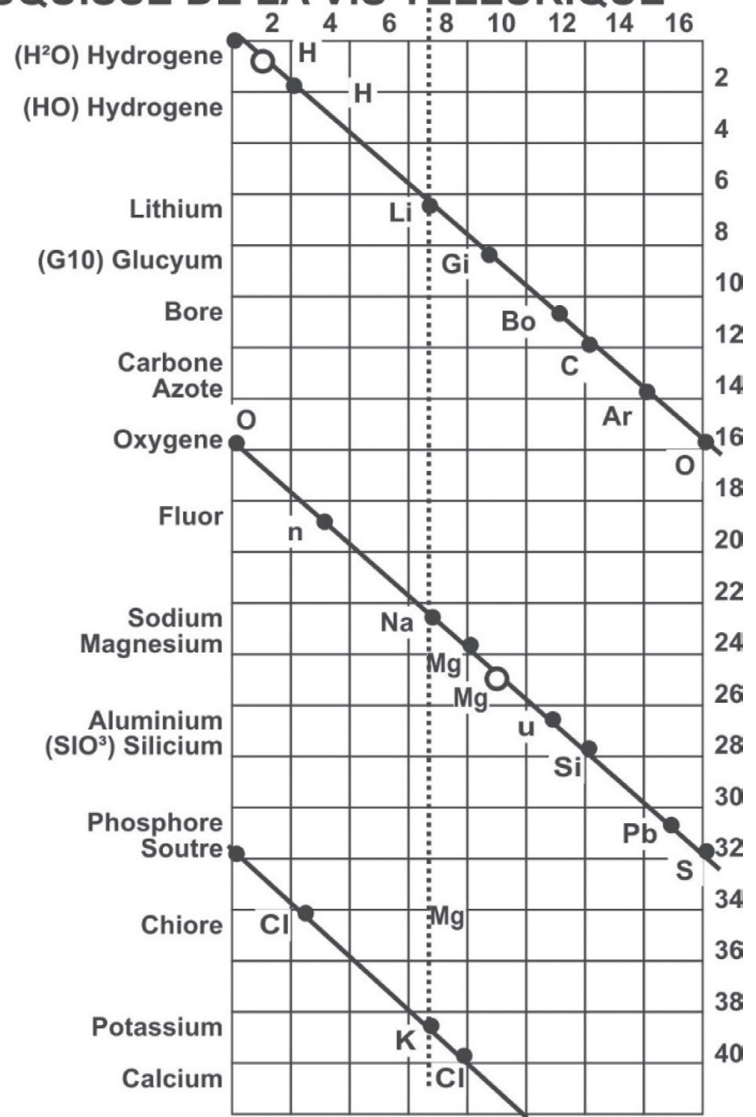

Figura 9. Os elementos dispostos da forma proposta por de Chancourtois, segundo o chamado "parafuso telúrico" (vis tellurique). Pode-se ver bem como elementos de propriedades semelhantes ficam na mesma vertical ${ }^{17}$

ligado à música, começou a publicar, a partir de 1863, uma série de artigos curtos na revista Chemical News, acerca das regularidades que ele percebia nos pesos atômicos dos elementos. Em 1865 ele sumarizou tudo e escreveu: "se os elementos forem arranjados na ordem de seus equivalentes, com algumas ligeiras transposições, como na tabela anexa, observar-se-á que elementos pertencentes ao mesmo grupo geralmente aparecem na mesma linha horizontal. Também se verá que os números de elementos análogos geralmente diferem entre si por 7 ou algum múltiplo de 7; em outras palavras, os membros do mesmo grupo estão em relação aos outros na mesma relação que as extremidades de uma ou mais oitavas na música." E mais adiante: "A esta relação peculiar proponho provisoriamente chamar 'Lei das Oitavas"'. A tabela de Newlands, com 62 elementos, pode ser vista na Figura $10 . .^{18}$

É curioso que a numeração dos elementos poderia ser chamada de uma sequência de "números atômicos", décadas antes que essa expressão surgisse, mas em outro contexto. Newlands foi obrigado a fazer uma inversão na tabela, como entre Te $\left(n^{\circ} 43\right)$ e I ( $\left.n^{\circ} 42\right)$, por puro pragmatismo, para atender à necessidade de colocar juntos elementos de propriedades semelhantes, assim como mais tarde faria Mendeleev. Apesar de sua ideia conter a semente de algo que frutificaria no futuro, ele foi muito criticado, ainda mais que a periodicidade não funcionava bem quando entravam em cena os elementos de transição. Ao apresentar suas ideias numa reunião da Chemical Society, em Londres, ele foi ridicularizado pelo Prof. George Carey Foster (1835-1919), que lhe perguntou se ele não havia também experimentado arranjar os elementos na ordem de suas letras iniciais e daí tirar conclusões químicas. O resultado de tudo isso foi que a Chemical Society recusou publicar a comunicação de Newlands. 


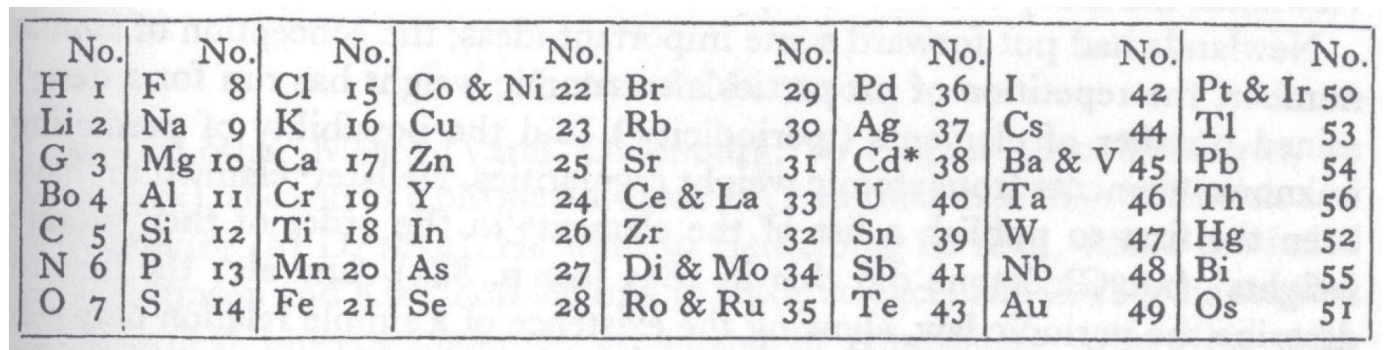

Figura 10. A Tabela das Oitavas de Newlands, por ele publicada em 1865, com 62 elementos, mostrando como após cada 7 elementos, dispostos nas colunas, iniciava-se uma nova oitava, como na música

Muitos anos depois, após o triunfo da tabela de Mendeleev, em 1887, Newlands foi reconhecido e a Royal Society lhe concedeu a Medalha Davy por seu papel pioneiro. ${ }^{19}$

\section{DMITRI IVANOVICH MENDELEEV}

Dmitri Ivanovich Mendeleev (1834-1907) nasceu em Tobolsk, na Sibéria. ${ }^{20}$ Após um começo de vida difícil, ele estudou química e realizou um mestrado em São Petersburgo em 1856, sendo então nomeado para lecionar química orgânica e físico-química na universidade. $^{21}$

Em 1859 Mendeleev ganhou uma bolsa de estudos para se aperfeiçoar na Universidade de Heidelberg, então um centro de muita importância na química. Além dos professores Bunsen e Kirchhoff, lá estavam muitos químicos jovens da geração de Mendeleev, como Friedrich August Kekulé (1829-1896), Adolf von Baeyer (18351917), Emil Erlenmeyer (1825-1907), Henry Roscoe (1833-1915), Lothar Meyer (1830-1895), Konrad Beilstein (1838-1906), Alexander Butlerov (1828-1906) e Alexandre Borodin (1833-1887).

Mendeleev fora a Heidelberg com a intenção de trabalhar em química orgânica com Bunsen, mas percebeu que o professor alemão estava agora completamente entretido com seus estudos de espectroscopia, e pouco interessado na química orgânica. ${ }^{22}$

Por isso o russo montou um laboratório em casa, onde passou a determinar constantes físicas, que depois lhe foram úteis ao descrever as propriedades dos elementos, tanto conhecidos como por descobrir, em sua Classificação Periódica, que surgiria em 1869. Mendeleev passou dois anos em Heidelberg, de 1859 a 1861. Nesse tempo teve oportunidade de ir ao $1^{\circ}$ congresso internacional de química, em Karlsruhe, convocado em 1860 pelos alemães Friedrich Kekulé e Karl Weltzien (1813-1870), e o francês Charles Adolphe Wurtz $(1817-1884))^{22}$

O mérito do Congresso de Karlsruhe se deveu a iniciativa do professor italiano Stanislao Cannizzaro (1826-1910). Cannizzaro publicara em 1858 um livro na Universidade de Gênova, em que havia utilizado com vantagem a esquecida Hipótese de Avogadro, de 1811, e que era ignorada pela maioria dos químicos. Pela hipótese, hoje Princípio de Avogadro, ficava clara a distinção entre átomos e moléculas, e muitos dos problemas da época, sobretudo a respeito das fórmulas moleculares corretas dos compostos, simplesmente sumiam. A literatura da época registrava, por exemplo, mais de dez fórmulas moleculares diferentes para uma substância tão comum como o ácido acético. Ao final do congresso, Angelo Pavesi, colega de Cannizzaro em Pavia, distribuiu, aos participantes, cópias do trabalho de Cannizzaro. ${ }^{23}$ Esta publicação impressionou o químico alemão Lothar Meyer (1830-1895), que, em seu livro As Teorias Modernas da Química e seu Significado para a Estática Química (1864), incorporou as idéias de Cannizzaro e Avogadro, resolvendo as querelas sobre os conceitos de átomo e molécula. Este livro teve enorme sucesso e foi traduzido em várias línguas europeias. ${ }^{24}$

A partir de suas coleções de fichas com constantes físicas dos elementos, Mendeleev, já há muito de volta à Rússia, e estabelecido como professor universitário de Química em São Petersburgo, descobriu, após muitas tentativas e erros, uma forma de ordenar os elementos conhecidos segundo a ordem crescente de pesos atômicos, em períodos e famílias. Dentro de uma família ficavam elementos com propriedades químicas parecidas, de sorte que havia uma sequência lógica em famílias, com bastante coerência química.

Por duas vezes, ele teve que inverter a ordem de pesos atômicos crescentes, e o fez por puro pragmatismo, pois era assim que dava certo, embora ele não soubesse a razão disso. Essa inversão ocorria para os pares $\mathrm{Co}(58,9)$ e $\mathrm{Ni}(58,7), \mathrm{Te}(127,6)$ e I $(126,9)$. Após a descoberta dos gases nobres no final do século XIX o mesmo se verificou para o par $\operatorname{Ar}(39,9)$ e $K(39,1)$.

Como na época não se conhecia o fenômeno da isotopia, nem o conceito de número atômico, a solução foi permitir as inversões quando isso se fazia necessário, sem qualquer justificativa racional.

Mendeleev inicialmente publicou sua tabela na Rússia, em 1869, Figura $11^{25}$, mas no mesmo ano voltou a publicá-la, desta vez em alemão, visando atingir uma audiência maior. ${ }^{26} \mathrm{~A}$ Figura 12 mostra esta Tabela Periódica original de Mendeleev em alemão, publicada na revista Zeitschrift für Chemie. Ela contém 63 elementos, o dobro dos elementos conhecidos por Lavoisier 80 anos antes. Notam-se lacunas para elementos desconhecidos, como o gálio, previsto com o nome provisório de eka-alumínio, com peso atômico 68, e descoberto por Paul-Émile Lecoq de Boisbaudran (1838-1912) em 1875, com peso atômico 69,9. Mendeleev havia dado a elementos desconhecidos após um dado elemento conhecido o nome deste precedido da partícula $e k a$, primeiro em sânscrito. Uma lacuna, duas posições após um elemento conhecido, era chamada pelo nome do elemento conhecido precedido da partícula sânscrita $d v i$, significando segundo. Por exemplo, os elementos que se seguem ao manganês, que só viriam a ser descobertos no século XX, como adiante se verá, foram chamados de eka-manganês (tecnécio) e dvi-manganês (rênio). A lacuna para o que Mendeleev chamava de eka-boro, de peso atômico previsto 44, levou ao descobrimento do escândio, por Lars Fredrik Nilson (1840-1899) em 1879, com peso atômico 44,1. Já a lacuna do eka-silício, com peso atômico previsto de 72, levou à descoberta do germânio, descoberto por Clemens Alexander Winkler (1838-1904) em 1886, com peso atômico 72,3. Os nomes desses novos elementos ilustram bastante o grau de exacerbação nacionalista que vigorava na época, e que eventualmente desaguaria na Grande Guerra de 1914.

Em 1871 Mendeleev preparou e enviou para publicação na Alemanha duas novas versões de sua tabela, com algumas alterações.

Essas duas versões, uma vertical e a outra horizontal, foram publicadas na mesma revista, Annalen der Chemie und Pharmazie. As Figuras 13 e 14 mostram estas duas novas versões da Tabela. Na segunda (Figura 14), os elementos cobre, prata e ouro aparecem duplicados, tanto no Grupo I como no VIII. Por isso aqui aparecem 66 elementos (3 repetidos), enquanto nas tabelas anteriores o número de elementos era 63. 


\section{0ІІЫТ СИСТЕМЫ ЭЛЕМЕНТОВТ.}

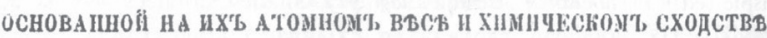

$$
\begin{aligned}
& \mathrm{Ti}=50 \quad \mathrm{Zr}-90 \quad ?=-180 . \\
& \begin{array}{lll}
V=-51 & \mathrm{Nb}=94 \quad \mathrm{~T} \mathrm{a}=182 .
\end{array} \\
& \mathrm{Cr}=52 \quad \mathrm{Mo}_{0}=9.96 \quad \mathrm{~W}=186 . \\
& M ॥=55 \quad R h==104,4 \quad P L=197 \text {, } \\
& \text { Fe }=56 \quad R 11=104,4 \text { Ir }-198 \text {. } \\
& \mathrm{Xi}=\mathrm{Co}=59 \quad \mathrm{Pl}=106, " \mathrm{O} ; \cdots 199 \text {. } \\
& H=1 \\
& \mathrm{Cu}=63,+\mathrm{Ag}: 10 \mathrm{~S} \quad \mathrm{Hg}=200 . \\
& \mathrm{Be}=9,+\mathrm{Mg}=24 \mathrm{Zn}:=6 \tilde{5}, 2 \quad \mathrm{Cd}=-=112 \\
& \mathrm{~B}=11 \quad \mathrm{Al}=27,+\quad ?=68 \quad \mathrm{Cr}-116 \quad \mathrm{All}=197 \text { ? } \\
& \mathrm{C}=12 \quad \mathrm{Si}=28 \quad ?=70 \quad \mathrm{Sn}=118 \\
& \mathrm{~N}=14 \quad \mathrm{P}=31 \quad \mathrm{As}=75 \quad \mathrm{Sb}=122 \quad \mathrm{Bi}-210 \text { ? } \\
& 0=16 \quad \mathrm{~S}=32 \quad \mathrm{Se}=79,4 \quad \mathrm{Te}=128 \text { ? } \\
& \mathrm{F}=19 \quad \mathrm{Cl}=35,5 \mathrm{Br}=80 \quad \mathrm{I}=127 \\
& \mathrm{Li}=7 \quad \mathrm{Na}=23 \quad \mathrm{~K}=39 \mathrm{Rb}=85,4 \quad \mathrm{Cs}=133 \quad \mathrm{~T} \mathrm{I}=204 \\
& \mathrm{Ca}=40 \quad \mathrm{Sl}=87,6 \quad \mathrm{Ba}=137 \quad \mathrm{~Pb}=207 . \\
& ?=-45 \quad \mathrm{Ce}=92 \\
& ? \mathrm{Er}=56 \quad \mathrm{La}=94 \\
& P Y \mid=60 \quad \mathrm{Di}=95 \\
& P \mathrm{hn}=75,{ }^{15} \mathrm{Th}=118 ?
\end{aligned}
$$

Figura 11. A Tabela original de Mendeleev, de 1869, publicada na Rússia ${ }^{26}$

\section{A TABELA PERIÓDICA DE LOTHAR MEYER}

Julius Lothar Meyer (1830-1895) nasceu em Varel, na Alemanha. Em 1854 recebeu diploma de médico pela Universidade de Würzburg e depois estudou química em Heidelberg, com Bunsen e Kirchhoff. Em 1858 recebeu um doutorado em química pela Universidade de Breslau, sobre os efeitos do monóxido de carbono no sangue. Por influência de Kirchhoff passou a estudar física matemática em Königsberg e tornou-se professor de física e química em Breslau. Foi depois professor em Karlsruhe e finalmente em Tübingen.

Em 1868 Meyer, que nunca assinou seu primeiro nome, Julius, desenvolveu ideias anteriores e criou em 1869 a Tabela mostrada na
Ueber die Beziehungen der Eigenschaften zu den Atomgewichten der Elemente. Von D. Mendelejeff. - Ordnet man Elemente nach zunehnisnden Atomgewichten in verticale Reihen so, dass die Horizontalreihen analoge Elemente enthalten, wiedsr nach zunehmendem Atomgewicht geordnet, so erhält man folgende Zusammenstellung, aus der sich einige allgemeinere Folgerungen ableiten lassen.

$$
\begin{aligned}
& \begin{array}{rrr}
\mathrm{Ti}=50 & \mathrm{Zr}=90 & ?=180 \\
\mathrm{~V}=51 & \mathrm{~Tb}=94 & \mathrm{Ta}=182
\end{array} \\
& \mathrm{Cr}=52 \quad \mathrm{Mo}=96 \quad \mathrm{~W}=\mathbf{1 8 6} \\
& \begin{array}{lll}
\mathrm{Mn}=55 & \mathrm{Rh}=104,4 & \mathrm{Pt}=197,4
\end{array} \\
& \mathrm{Fe}=56 \quad \mathrm{Ru}=104,4 \quad \mathrm{Ir}=198 \\
& \mathrm{Ni}=\mathrm{Co}=59 \quad \mathrm{Pd}=106,6 \quad \mathrm{Os}=199 \\
& \begin{array}{ccccc}
\mathrm{H}=1 & & \mathrm{Cu}=63,4 & \mathrm{Ag}=108 & \mathrm{Hg}=200 \\
\mathrm{Be}=9,4 & \mathrm{Mg}=24 & \mathrm{Zn}=65,2 & \mathrm{Cd}=112 & \\
\mathrm{~B}=11 & \mathrm{Al}=27,4 & ?=68 & \mathrm{Ur}=116 & \mathrm{Au}=197 ? \\
\mathrm{C}=12 & \mathrm{Si}=29 & ?=70 & \mathrm{Sn}=118 &
\end{array} \\
& \begin{array}{llrlr}
\mathrm{C}=12 & \mathrm{Si}=29 & ?=70 & \mathrm{Sn}=118 & \mathrm{Bi}=210 ? \\
\mathrm{~N}=14 & \mathrm{P}=31 & \mathrm{As}=75 & \mathrm{Sb}=122 & \mathrm{Bi}=210
\end{array} \\
& \mathrm{~S}=32 \quad \mathrm{Se}=79,4 \quad \mathrm{Te}=128 \text { ? } \\
& \begin{array}{lll}
\mathrm{S}=32 & \mathrm{Se}=79,4 & \mathrm{Te}=128 \\
\mathrm{Cl}=35,5 & \mathrm{Br}=80 & \mathrm{~J}=127
\end{array}
\end{aligned}
$$

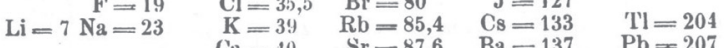

$$
\begin{aligned}
& \mathrm{Ca}=40 \quad \mathrm{Sr}=87,6 \quad \mathrm{Ba}=137 \quad \mathrm{~Pb}=207 \\
& ?=45 \quad \mathrm{Ce}=92 \\
& ? \mathrm{Er}=56 \quad \mathrm{La}=94 \\
& \begin{array}{ll}
? \mathrm{Yt}=60 & \mathrm{Di}=95 \\
\text { ? } & =65,6
\end{array}
\end{aligned}
$$

1. Die nach der Grösse des Atomgewichts geordneten Elemente zeigen eine stufenweise Abänderung in den Eigenschaften.

2. Chemisch-analoge Elemente haben entweder übereinstimmende Atomgewichte (Pt, Ir, Os), oder letztere nehmen gleichviel zu (K, Rb, Cs).

3. Das Anordnen nach den Atomgewichten entspricht der Werthigkeil der Elemente und bis zu einem gewissen Grade der Verschiedenheit im chemischen Verhalten, z. B. Li, Be, B, C, N, 0, F

4. Die in der Natur verbreitetsten Elemente haben kleine Atomgewichte

Figura 12. A primeira Tabela de Mendeleev em alemão, publicada no mesmo ano de 1869, com o título (traduzido) de "Sobre as Relações das Qualidades para os Pesos Atômicos dos Elementos"26

Figura 15, com 52 elementos, que foi publicada em 1870.

$\mathrm{O}$ artigo original de Meyer também apresenta uma curva de volume atômico contra peso atômico, que mostra claramente a periodicidade daquela variável para os diversos elementos (Figura 16).

O cálculo dos volumes atômicos foi feito por Lothar Meyer da seguinte maneira, descrita aqui em termos modernos: volume atômico $=$ peso atômico/densidade $(\mathrm{PA} / \mathrm{d})$, ou $\mathrm{g} \mathrm{mol}^{-1} / \mathrm{g} \mathrm{cm}^{-3}=\mathrm{cm}^{3} \mathrm{~mol}^{-1}$

O gráfico de Meyer funciona bem, exceto quando os elementos admitem mais de um alótropo. Neste caso, o volume atômico pode diferir bastante de um alótropo para outro.

Exemplos:

Diamante: $\mathrm{d}=3,51 \mathrm{~g} \mathrm{~cm}^{-3}$

Grafita: $\mathrm{d}=2,2 \mathrm{~g} \mathrm{~cm}^{-3}$

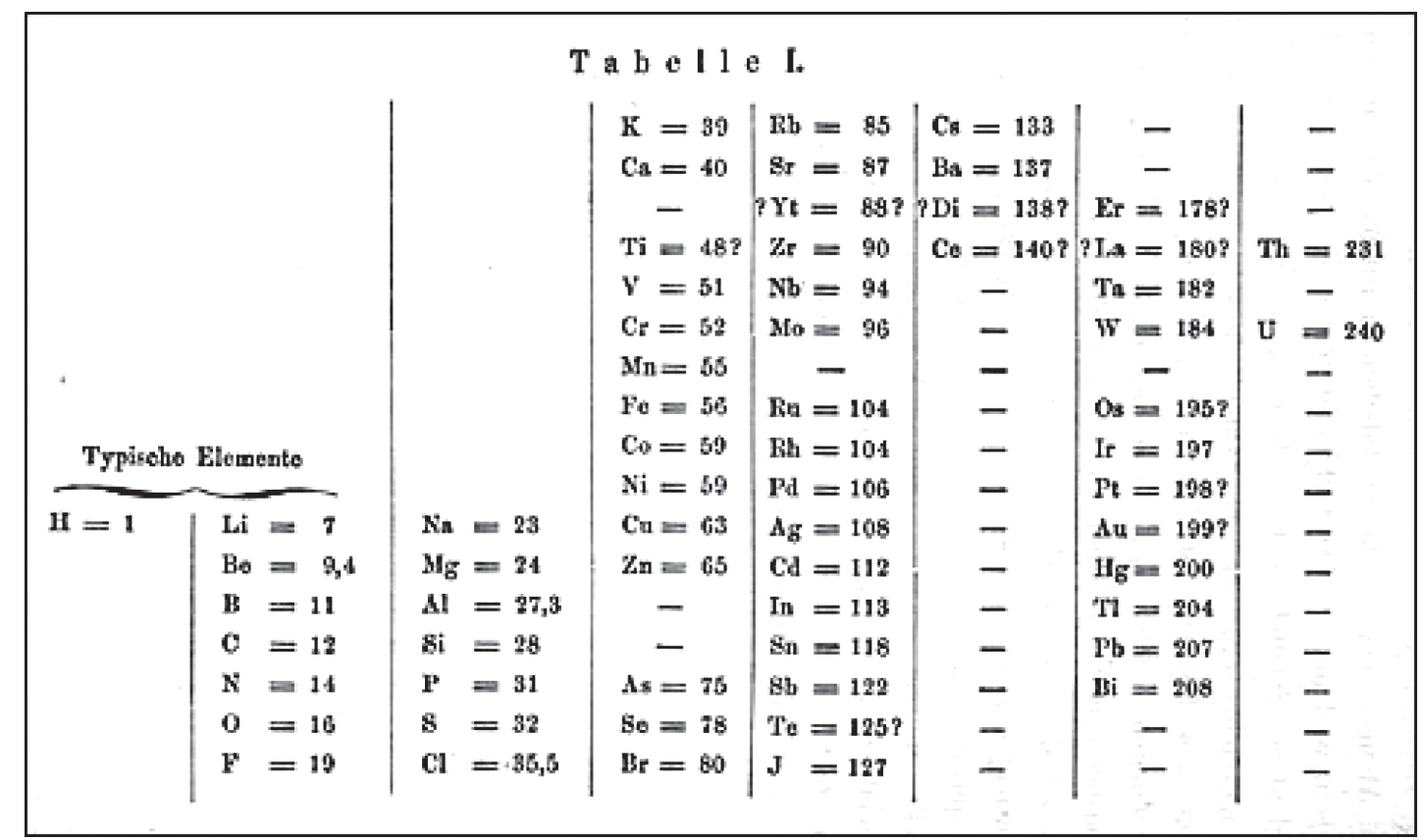

Figura 13. A Tabela de Mendeleev na forma vertical, em versão de 1871, mas publicada em $1872^{27}$ 


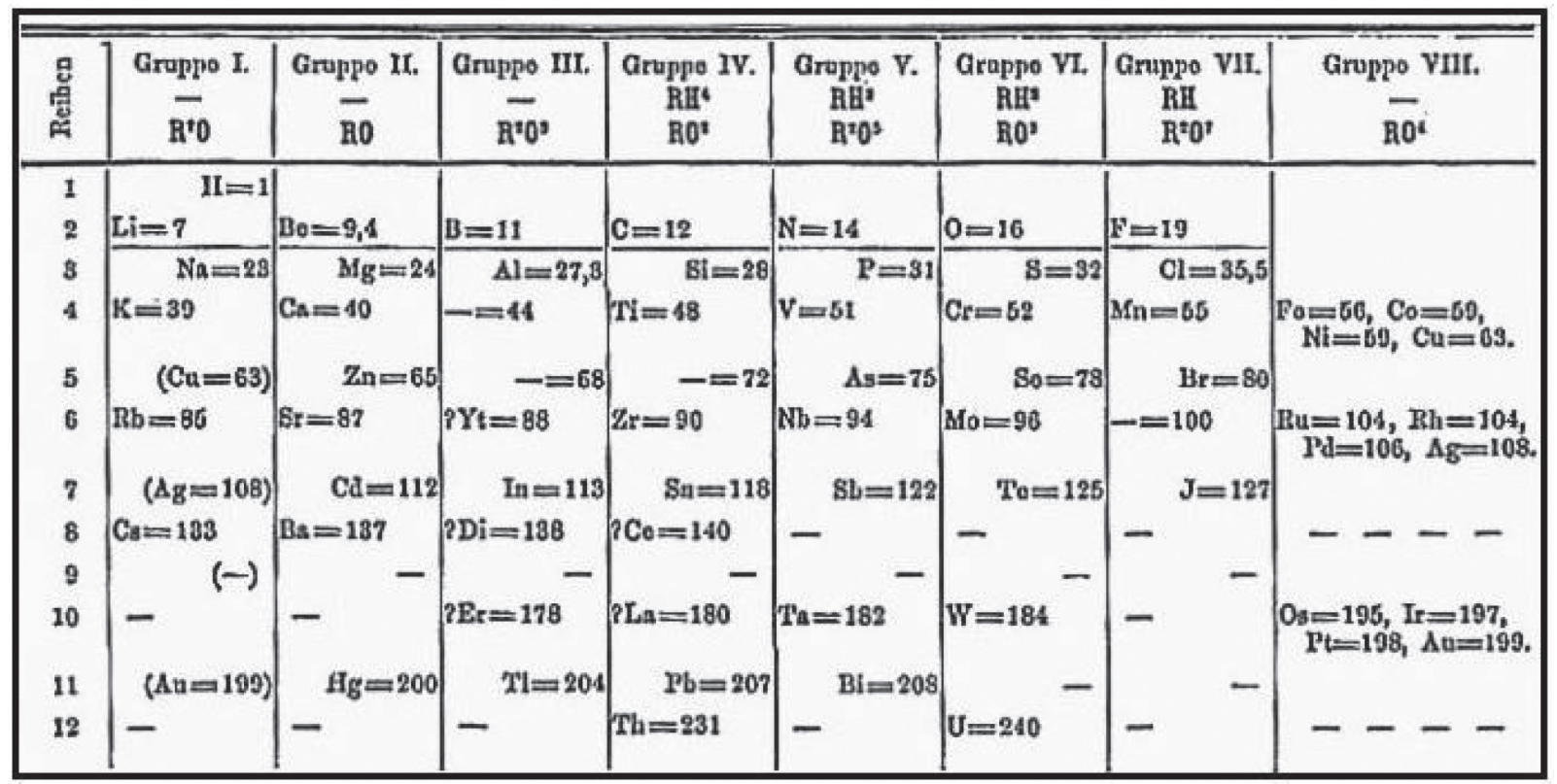

Figura 14. A Tabela de Mendeleev na forma horizontal, em versão de 1871, publicada em 1872. ${ }^{27}$

\begin{tabular}{|c|c|c|c|c|c|c|c|}
\hline I & II & III & IV & v & VI & VII & VIII \\
\hline - & - & - & - & - & - & - & - \\
\hline 二 & 三 & $\mathrm{Al}_{\overline{27}} \overline{3}$ & $A \overline{27} \cdot 3$ & $=$ & $\overline{-}$ & Z & $\bar{C} \overline{12} \cdot 0$ \\
\hline - & - & $\frac{28.7}{7}=14.3$ & - & - & - & - & $16 \cdot 5$ \\
\hline - & - & ${ }^{2}-$ & - & - & - & - & Si 28.5 \\
\hline - & - & - & - & - & - & - & $\frac{89.1}{2}=44.55$ \\
\hline $\mathrm{Cr} 52 \cdot 6$ & Mn $55^{\cdot I}$ & $\mathrm{Fe}{ }_{56.0}$ & Co 58.7 & $\mathrm{Ni} 58.7$ & $\mathrm{Cu} 63.5$ & $\operatorname{Zn} 65^{\circ} 0$ & ${ }^{2}-$ \\
\hline- & $49 \cdot 2$ & $48 \cdot 3$ & $47 \cdot 3$ & - & $44 \cdot 4$ & $46 \cdot 9$ & $\frac{89.1}{2}=44.55$ \\
\hline 三 & 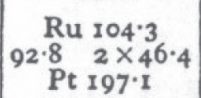 & $\begin{array}{c}\mathrm{Rh} 104 \cdot 3 \\
92 \cdot 8=2 \times 46 \cdot 4 \\
\operatorname{Ir} 197 \cdot \mathrm{I}\end{array}$ & $\begin{array}{c}\text { Pd r ro6.0 } \\
93=2 \times 46 \cdot 5 \\
\text { Os r } 199 \cdot 0\end{array}$ & $\bar{z}$ & $\begin{array}{c}\mathrm{Ag} \text { 107.94 } \\
88 \cdot 8 \quad 2 \times 44 \cdot 4 \\
\mathrm{Au} 196 \cdot 7\end{array}$ & $\begin{array}{c}\mathrm{Cd} \times \mathrm{xrr} \cdot 9 \\
88.32 \times 44 \cdot 15 \\
\mathrm{Hg} 200 \cdot 2\end{array}$ & 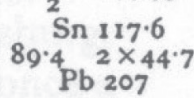 \\
\hline
\end{tabular}

\begin{tabular}{|c|c|c|c|c|c|c|c|}
\hline IX & $\mathrm{X}$ & XI & XII & XIII & XIV & $X V$ & XVI \\
\hline $\begin{array}{c}\bar{Z} \\
\mathrm{~N}_{14.04} \\
16.96 \\
\mathrm{P}_{31.0} \\
44.0 \\
\mathrm{As} 75.0 \\
45.6 \\
\mathrm{Sb}_{120.6} \\
87.4=2 \times 43.7 \\
\mathrm{Bi} 208\end{array}$ & $\begin{array}{c}- \\
\text { O } 16 \\
16 \cdot 07 \\
\mathrm{~S} 32 \cdot 07 \\
46 \cdot 7 \\
\mathrm{Se} 78 \cdot 8 \\
49 \cdot 5 \\
\mathrm{Te}_{128.3} \\
=\end{array}$ & 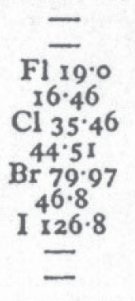 & $\begin{array}{c}\mathrm{Li} 7.03 \\
16.02 \\
\mathrm{Na} \mathrm{23.05} \\
16.08 \\
\mathrm{~K} 39.13 \\
46.3 \\
\mathrm{Rb}^{4} .4 \\
47.6 \\
\mathrm{Cs} 133.0 \\
7 \mathrm{I}=2 \times 35 ; 5 \\
\text { ? } \mathrm{Tl} 204 \text { ? }\end{array}$ & $\begin{array}{c}\mathrm{Be} \mathrm{9 \cdot 3} \\
14 \cdot 7 \\
\mathrm{Mg}_{24} 4 \cdot 0 \\
16 \\
\mathrm{Ca} 40 \cdot 0 \\
47 \cdot 6 \\
\mathrm{Sr}^{4} 87 \cdot 6 \\
49 \cdot 5 \\
\mathrm{Ba}_{137 \cdot 1} \\
=\end{array}$ & 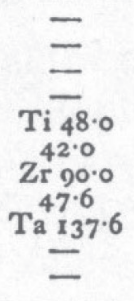 & $\begin{array}{c}\bar{z} \\
\bar{z} \\
\mathrm{Mo} 92^{45} \\
\mathrm{v}_{137} \\
\mathrm{w}^{47}{ }^{4} 4 \\
\bar{z}\end{array}$ & $\begin{array}{l}\bar{z} \\
\bar{z} \\
\bar{z} \\
\bar{z}\end{array}$ \\
\hline
\end{tabular}

Figura 15. A Tabela Periódica de Lothar Meyer, versão não-publicada de $1868 .^{28}$ Em 1869 ele a redigiria novamente com pequenas alterações, um pouco depois de Mendeleev, vindo a publicá-la em $1870 .{ }^{29}$ Segundo o próprio Meyer, sua tabela é essencialmente idêntica àquela publicada por Mendeleev", e ele não fez questão de reclamar qualquer originalidade sobre este aspecto ${ }^{30}$

Volume atômico do diamante $=12 / 3,51=3,42 \mathrm{~cm}^{3} \mathrm{~mol}^{-1}$ Volume atômico da grafita $=12 / 2,2=5,45 \mathrm{~cm}^{3} \mathrm{~mol}^{-1}$

Em virtude de incertezas na Tabela de Meyer, como a que foi apresentada, e em razão da melhor capacidade da Tabela Periódica de Mendeleev em fazer previsões, esta acabou superando aquela.

\section{PEDRO II E A TABELA PERIÓDICA}

Após a publicação da Tabela Periódica, isso é, após 1869, novos elementos previstos por Mendeleev foram sendo descobertos, começando pelo gálio em 1875 , seguido pelo escândio em 1879 e pelo germânio em 1886. Um aspecto muito pouco conhecido de nossa história diz respeito ao interesse do Imperador D. Pedro II por essas novas descobertas químicas.$^{32}$

A Fundação Maria Luísa e Oscar Americano, em São Paulo, possui um manuscrito do próprio punho de D. Pedro II, que é bastante revelador a respeito da atualidade, do grau e da profundidade do conhecimento químico do soberano (Figura 17).

$\mathrm{O}$ manuscrito parece ser uma folha de caderno, escrito a lápis na difícil grafia do Imperador, que estava longe de ser um calígrafo. Trata-se de anotações para estudo a respeito de quatro novos elementos, com a data 1879 escrita pelo Imperador, o próprio ano da descoberta do escândio pelo químico sueco Lars Nilson. O documento está em forma de uma tabela, composta de sete colunas rotuladas 


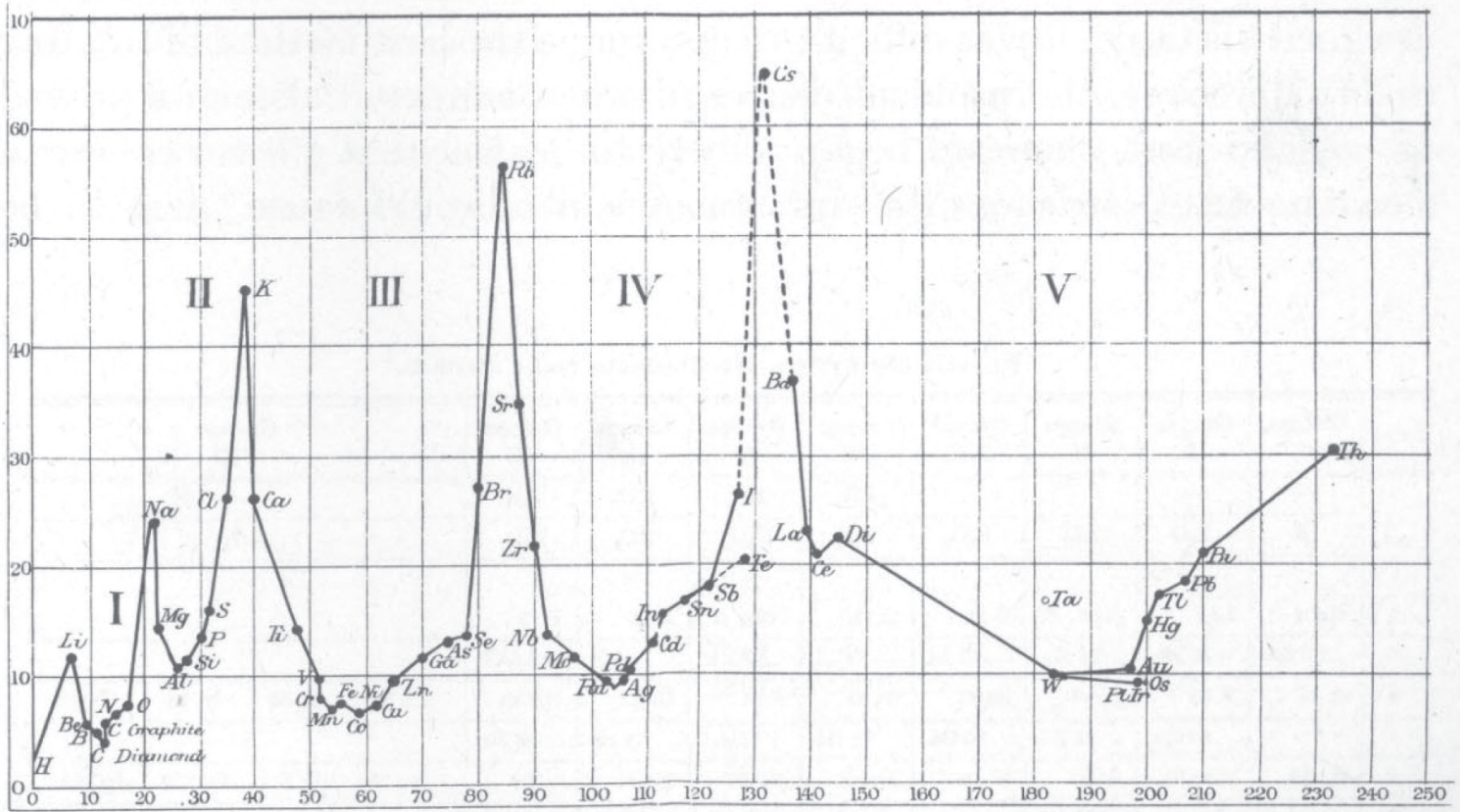

Figura 16. Curva de volume atômico contra peso atômico, apresentada por Lothar Meyer em 1870, mostrando a variação periódica dessa propriedade. Como exemplo, os máximos da curva são todos ocupados pelos elementos alcalinos ${ }^{31}$

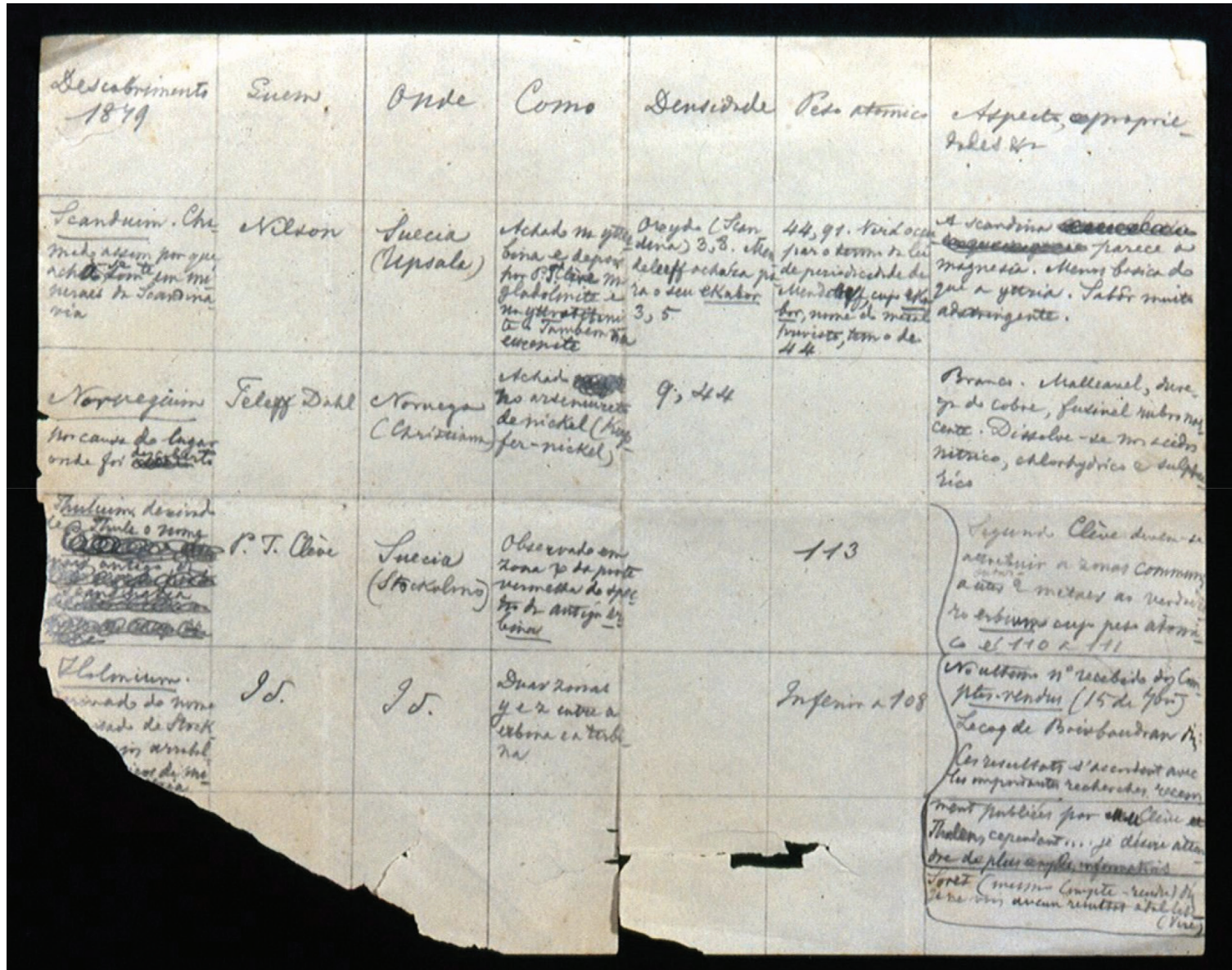

Figura 17. Manuscrito de D. Pedro II, com sua tabela relativa aos novos elementos descobertos (1879). Fundação Maria Luísa e Oscar Americano, São Paulo

Descobrimento, Quem, Onde, Como, Densidade, Peso atômico, e Aspecto, Propriedades, etc.

O primeiro elemento é o escândio, o qual vem assim descrito, mantendo-se a grafia do Imperador:
Descobrimento: Scandium - Chamado assim porque acha-se somente em minerais da Scandinavia.

Quem:

Onde:

Como:
Nilson

Suécia (Upsala)

Achado na Yterbina e depois por P. T. Cleve 
na gladolinite e na Yttratibinite. Também na europite.

Densidade: $\quad$ Oreydo (scandina) 3,8. Mendeleeff achava para o seu ekabor 3,5.

Peso atômico: $\quad 44,91$. Visto ocupar o termo da lei de periodicidade de Mendeleeff, cujo ekabor, nome do metal previsto, tem o valor de 44 .

Aspecto, propriedades, etc.: A Scandina parece a magnésia. Menos básica do que a Yttria. Sabor muito adstringente.

Os elementos seguintes na tabela de D. Pedro II são o norvégio, o túlio e o hólmio. O norvégio foi um equívoco científico, pois o que se supunha ser um novo elemento mostrou-se depois ser uma mistura de ítrio e háfnio. No entanto, sua "descoberta" e consequente relato pelo mineralogista norueguês Tellef Dahll ocorreu também no ano de 1879, o que novamente mostra a atualização do Imperador face às publicações científicas de seu tempo. ${ }^{33}$

Ao descrever como foi descoberto o túlio, o Imperador demonstra ter conhecimento de espectroscopia: "Observado em zona x da parte vermelha do spectro do antigo erbium."

Já ao tratar do hólmio, evidencia com minúcias sua familiaridade com a literatura corrente, que ele recebia como membro da Academia das Ciências de Paris. O interessante é que o Imperador lia, anotava e comentava os trabalhos científicos sobre o assunto publicados nos Comptes Rendus (dados neste caso nas referências 34 e 35), o periódico oficial da Academia, como se pode constatar aqui. Este é o texto de D. Pedro II:

"No último no recebido dos Comptes Rendus (15 de jan) Lecoq de Boisbaudran diz: Ces résultats s'accordent avec les importantes recherches récemment publiées par $M$. de Cleve et Thielen, cependant ... je désire attendre de plus amples informations. Soret (mesmo Comptes Rendus) diz: Je ne vois aucun résultat établissant que l'holmium soit um corps différent. Acrescenta: Si ni moi ni M. Marignac ... nous n'avons pas tiré alors de conclusion positive de ces faits c'est qu'il nous a paru que ... il est peut-être prématuré d'affirmer l'existence d'um élément nouveau quand il est encore impossible de l'isoler et d'en determiner les caractères chimiques, en se basant seulement sur la présence d'une unique raie du spectre d'absorption."

Tradução do texto: "Estes resultados concordam com as importantes pesquisas publicadas recentemente por $M$. Cleve e Thielen, entretanto .... desejo esperar informações mais amplas. Soret (mesmo Comptes Rendus) diz: Não vejo qualquer resultado estabelecendo que o hólmio seja um corpo diferente. Acrescenta: Se nem eu nem M. Marignac ... tiramos então conclusão positiva destes fatos é porque pareceu-nos que ... é talvez prematuro afirmar a existência de um elemento novo quando é ainda impossível isolá-lo e determinar-lhe os caracteres químicos, baseando-se apenas na presença de uma única raia do espectro de absorção."

No caso do artigo de Lecoq de Boibaudran, o Imperador faz uma citação ligeiramente modificada, ao passo que quanto a Soret sua citação é literal, o que é notável em termos de sua acurácia em relatar uma publicação científica que havia lido. ${ }^{34,35}$

Um outro pormenor interessante é a anotação de D. Pedro II ao dizer que ele havia lido os textos citados "no último $\mathrm{n}^{\circ}$ recebido dos Comptes Rendus (15 de jan)". Ora, os dois artigos haviam sido publicados em 15 de setembro de 1879 , logo a data anotada pelo Imperador deve ter sido aquela do recebimento da revista por ele no Rio de Janeiro, que deve referir-se a 15 de janeiro de 1880, o que dá uma ideia do tempo necessário para se receber uma revista científica europeia no Brasil.

Não se conhece outro governante no mundo, no século XIX, com esse interesse e familiaridade com a ciência. Desse modo, D. Pedro II estava absolutamente em dia com a Química de seu tempo, talvez até mais atualizado que muitos professores da disciplina no Brasil da época.

\section{A DESCOBERTA DOS GASES NOBRES}

Ao final do século XIX, só se conhecia um gás nobre, o hélio, e só no Sol. Como já foi mencionado acima, em 1895 ele foi identificado também na Terra, por William Ramsay e independentemente também por outros. No entanto, onde ficaria na Tabela Periódica? Isto só se resolveu com a descoberta de seus homólogos mais pesados.

A descoberta do próximo gás nobre tem um aspecto curioso, pois foi o único caso de uma descoberta científica importante feita em consequência do conhecimento da História da Ciência. Muitas vezes vemos alguém querer justificar a História da Ciência como possível fonte de inspiração para futuras descobertas científicas, mas essa justificativa é falsa. A História da Ciência é importante, mas por outras razões.

O maior protagonista da descoberta de uma nova coluna na Tabela Periódica foi o escocês William Ramsay (1852-1916), tornando-se por isso o primeiro britânico a receber o Prêmio Nobel de Química, em 1904.

Ramsay entrou para a Universidade de Glasgow aos 14 anos, mas deixou-a, completando os estudos na Alemanha. Inicialmente estudou sob Bunsen em Heidelberg. Em 1872, aos 20 anos, concluiu um doutorado em Química Orgânica, em Tübingen, sob Rudolf Fittig.

Retornando ao Reino Unido, Ramsay passou por Bristol, e em seguida Londres, iniciando colaboração com o físico Lord Rayleigh (John William Strutt, Lord Rayleigh, 1842-1919).

Rayleigh descobrira que o nitrogênio atmosférico é $0,5 \%$ mais denso que o nitrogênio obtido de compostos que o contêm. Henry Cavendish (1731-1810) havia descoberto o mesmo no século XVIII. Cavendish, um dos mais meticulosos cientistas de seu tempo, analisara o ar e descobrira que depois de eliminar toda a umidade e o gás carbônico do ar, e após reagir meticulosamente o oxigênio e o nitrogênio (este por ação de uma faísca elétrica), sempre restava um resíduo totalmente inerte, que correspondia a 1/120 do ar. Por mais que tentasse descobrir uma solução para o problema, Cavendish não conseguiu deslindá-lo. Ele apenas sabia que aquele resíduo parecia ser diferente do nitrogênio.

Conhecendo a observação de Cavendish de mais de um século antes, Rayleigh e Ramsay analisaram o espectro do resíduo e descobriram linhas espectrais novas. Sua conclusão foi então de que estavam diante de um novo elemento gasoso. Eles deram ao novo gás o nome de argônio, do grego para "preguiçoso", em virtude de sua inércia química. ${ }^{36}$

Apesar da evidência, eles tiveram forte oposição do químico James Dewar (1842-1923), que não aceitava a existência do argônio.

Ramsay, pesquisando os chamados "gases inertes", descobriu o resto da família. Seus teores volumétricos na atmosfera são: $\mathrm{Ar}=$ 0,93\%, $\mathrm{Ne}=20 \mathrm{ppm}, \mathrm{Kr}=1 \mathrm{ppm}, \mathrm{Xe}=0,1 \mathrm{ppm}$. Em 1903 Ramsay se associou a Frederick Soddy para estudar um gás produzido pelo Ra, que Rutherford denominava “emanação”. Este gás era o radônio, altamente radioativo. ${ }^{37}$

Após a descoberta do argônio, Lecoq de Boisbaudran sugeriu que a Tabela Periódica devia ser ampliada, introduzindo-se uma coluna adicional, a coluna zero, ou dos gases nobres (ainda por descobrir).

A partir de 1962, outro químico britânico, Neil Bartlett (19322008), mostrou experimentalmente que alguns gases "inertes" podem reagir, formando compostos. ${ }^{38}$ Por isso prefere-se hoje a expressão "gases nobres".

A Figura 18 é uma preciosidade, pois mostra juntas várias das personalidades descritas neste texto e ligadas à história da Tabela Periódica ou de novos elementos que se descobriram na segunda metade do século XIX. 


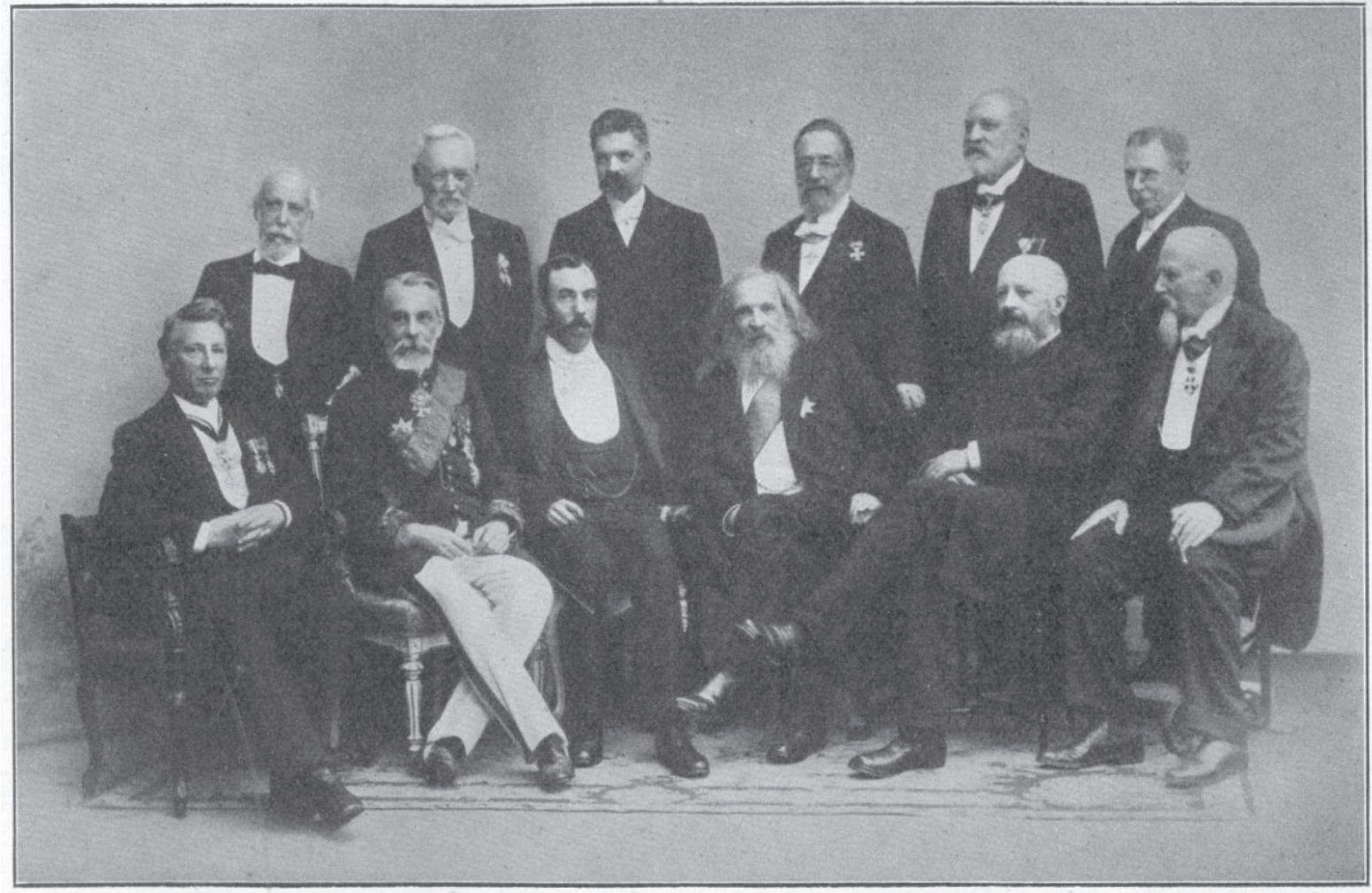

Vordere Reihe $\rightarrow$ van't Hoff.

Hintere Reihe $\rightarrow$

$$
\text { Ladenburg. Jörgensen. Hjelt. }
$$

Abb. 64.

Mendelejeff.

Landolt. von Baeyer. Cossa.

Winkler. Thorpe.

Figura 18. Foto tirada em 1900, quando da celebração do jubileu de 200 anos da Academia Prussiana das Ciências, em Berlim. Aparecem sentados: Jacobus Henricus van't Hoff (Holanda), Friedrich Konrad Beilstein (Rússia), William Ramsay (Escócia), Dmitri Mendeleev (Rússia), Adolf von Baeyer (Alemanha), Alfonso Cossa (Itália); em pé: Albert Ladenburg (Alemanha), Sophus Mads Jorgensen (Dinamarca), Edvard Hjelt (Finlândia, na época parte do Império Russo), Hans Heinrich Landolt (Alemanha), Clemens Alexander Winkler (Alemanha), Thomas Edward Thorpe (Inglaterra). Esta foto consta da biografia de van't Hoff publicada em 1912, um ano após sua morte, e mostra vários químicos envolvidos diretamente com a criação e desenvolvimento da Tabela Periódica e seus novos elementos ${ }^{39}$

\section{A DESCOBERTA DAS TERRAS RARAS}

Os elementos conhecidos genericamente como terras raras fazem parte do grupo três da tabela periódica e correspondem ao escândio ( $\mathrm{Sc}$, número atômico $\mathrm{Z}=21$ ), ítrio $(\mathrm{Y}, \mathrm{Z}=39$ ) e os quinze elementos denominados lantanídeos, cujos números atômicos variam de $\mathrm{Z}=57$ a $Z=71$. Os lantanídeos, em ordem crescente de número atômico são: lantânio $(\mathrm{La})$ cério $(\mathrm{Ce})$, praseodímio $(\mathrm{Pr})$, neodímio $(\mathrm{Nd})$, promécio $(\mathrm{Pm})$, európio $(\mathrm{Eu})$, gadolínio $(\mathrm{Gd})$, térbio $(\mathrm{Tb})$, disprósio (Dy), hólmio (Ho) érbio (Er), túlio (Tm), itérbio (Yb) e lutécio (Lu). As terras raras correspondem ao maior grupo de elementos naturais, representando $1 / 7$ de todos os elementos naturais conhecidos.

O termo "terras" era utilizado nos séculos XVIII e XIX para descrever os óxidos de metais alcalinoterrosos. Assim como os lantanídeos, o Sc e o Y foram obtidos originalmente na forma de óxidos, a partir de seus minerais. Em função disso, todos passaram a ser denominados genericamente de terras. $\mathrm{O}$ emprego do adjetivo raras está associado ao fato de esses elementos terem sido, inicialmente, obtidos a partir de poucos minerais restritos em pedreiras da Escandinávia. Além disso, devido à grande dificuldade de isolamento dos óxidos de cada elemento, eles eram obtidos em quantidades muito reduzidas, reforçando a ideia de que se tratava de elementos raros. Embora saibamos hoje que vários desses elementos são muito abundantes na crosta terrestre, a expressão "terras raras" continua sendo utilizada.
A história desses elementos teve início em 1788, com a descoberta de um mineral de cor escura, pelo Tenente Carl Axel Arrhenius (1757-1824), nas redondezas da pequena cidade de Ytterby, próxima a Estocolmo. Esse mineral foi posteriormente estudado pelo químico e mineralogista finlandês Johan Gadolin (1760-1852) que dele isolou, em 1794, uma nova terra, ou melhor, um óxido de um novo metal, que ele chamou de ítrio. O elemento apenas veio a ser obtido na forma metálica em 1828 por Friedrich Wöhler (1800-1882) por meio da reação do cloreto de ítrio com potássio metálico. Gadolin mostrou que o mineral era formado por $38 \%$ do óxido de ítrio. ${ }^{40}$

O elemento Yt foi incluído na tabela de Mendeleev de 1869 (Figura 12), com esse símbolo e peso atômico 60, mas junto a este dado aparece uma interrogação, indicando dúvida sobre sua natureza. Este mesmo elemento aparece na tabela de 1872 (Figura 14) com o peso atômico 88. Posteriormente o mesmo mineral - inicialmente chamado de Iterbita e posteriormente rebatizado de gadolinita, em homenagem a Gadolin - foi investigado por muitos outros pesquisadores que mostraram tratar-se de uma mistura de diversos óxidos de metais com características muito parecidas. Esses compostos passaram a ser chamados de terras ítricas, tendo sido identificadas um total de dez.

O químico suíço Carl Gustav Mosander (1797-1858) estudou o ítrio de Gadolin e mostrou que ele era na verdade constituído por três elementos: o próprio ítrio, que ele obteve na forma pura em 1843, o térbio $(\mathrm{Tb})$ e o érbio (Er). Dessa forma, foi Mosander, e não Gadolin, a obter o ítrio puro pela primeira vez. 
A partir dos trabalhos de Mosander no início da década de 1840, até 1907 , foram identificados a partir das terras ítricas mais nove elementos, sempre na forma de óxidos. Posteriormente mostrou-se que o térbio e o érbio de Mosander eram, na realidade, misturas de vários elementos. Essa confusão na identificação das terras raras prevaleceu por muito tempo, apesar do emprego - pelos pesquisadores - das análises espectroscópicas já disponíveis na época.

Em ordem cronológica, as terras ítricas foram descobertas pelos seguintes pesquisadores: 1794, ítrio, Gadolin; 1842, érbio, Mosander; 1843, térbio, Mosander; 1878, hólmio, Marc Delafontaine, Per Teodor Cleve e Soret; 1879, túlio, Cleve; 1879, escândio, Lars Nilson; gadolínio, Jean-Charles Galissard de Marignac; 1885, praseodímio e neodímio, Auer von Welsbach; 1886, disprósio, Lecoq de Boisbaudran; 1907, lutécio, Georges Urbain. ${ }^{41,42}$

Foram precisos pouco mais de 100 anos para que todas as terras itricas fossem identificadas. Nesse processo, muitas descobertas inicialmente relatadas como sendo de um novo elemento, na verdade eram misturas, sendo que a prioridade do descobrimento foi dada para o pesquisador que reportou a mistura inicial.

Como durante o século XIX ainda não existia o conceito de número atômico, não se sabia ao certo o número de terras raras existentes. O químico francês Georges Urbain (1872-1938), que por várias décadas se dedicou ao estudo desses elementos, mostrou que aproximadamente 20 elementos supostamente diferentes relatados na literatura, eram na verdade todos idênticos ao európio, gadolínio, térbio e disprósio. Segundo Urbain, muitos dos elementos reportados eram tão mal caracterizados que nem tinham lugar na tabela periódica. $^{43}$

Um outro grupo de elementos do grupo dos lantanídeos foi obtido do mineral denominado cerita, também conhecido como "pedra pesada de Bastnas". O primeiro elemento deste grupo a ser identificado foi o cério, obtido em 1803 na forma de óxido por Jöns Jacob Berzelius (1779-1848) e Wilhelm Hisinger (1776-1852). No mesmo ano, de forma independente, o químico Martin Heinrich Klaproth (1743-1817) isolou o mesmo óxido de um mineral então denominado terra ochroita. Nesse período esse óxido foi obtido de diversos outros minerais, sendo que alguns são constituídos quase que exclusivamente de sais de cério. ${ }^{42}$

Da cerita, além do cério, foram isolados, em ordem cronológica, os seguintes elementos: 1839, lantânio, Mosander; 1879, samário, de Boisbaudran; 1885, praseodímio e neodímio, von Welsbach; 1901, európio, Eugène Anatole Demarçay. ${ }^{42}$

Assim como no caso dos elementos isolados das terras ítricas, o estudo da cerita também resultou em muita confusão e diversos relatos de misturas de óxidos como se fossem compostos puros. O caso mais emblemático é do elemento denominado "didímio", que constava da primeira tabela de Mendeleev, tendo peso atômico 95 e símbolo Di (Figura 12). Na versão vertical dessa tabela, publicada em 1872 (Figura 15), o didímio (Di) aparece com peso atômico 138, com duas interrogações. Depois de muitos estudos, com o auxílio de análises espectroscópicas, o didímio não sobreviveu, tendo sido demonstrado que se tratava de uma mistura de praseodímio, neodímio, gadolínio, samário e európio. ${ }^{44}$

Outras terras raras tiveram os pesos atômicos e as posições alteradas na Tabela de 1872, aparecendo com muitas interrogações. Essas alterações indicam claramente que o próprio Mendeleev tinha dúvidas sobre a autenticidade dos dados referentes às terras raras.

$\mathrm{O}$ promécio $(\mathrm{Pm}, \mathrm{Z}=61)$ foi o último elemento pertencente ao grupo das terras raras a ser descoberto. Sua existência foi inicialmente proposta em 1902 pelo químico Bohuslav Brauner (1855-1935), natural da Tchecoslováquia e professor da Universidade de Praga. Em função da descontinuidade observada entre algumas propriedades do neodímio e do samário, Brauner propôs que deveria existir outro elemento entre esses dois. Isso foi confirmado em 1914 com o trabalho que Henry Moseley, ao determinar os números atômicos dos elementos, verificou que o correspondente a $\mathrm{Z}=61$ estava faltando na lista dos então conhecidos. A partir do trabalho de Moseley um grande número de pesquisadores, em várias partes do mundo, se concentrou na busca por esse elemento. Ao longo das décadas seguintes vários trabalhos foram feitos relatando a descoberta desse elemento, entretanto sem a devida confirmação experimental. Em 1938 um grupo de pesquisadores da Universidade do Estado de Ohio realizou experimentos, em um cíclotron, bombardeando praseodímio e neodímio com nêutrons e partículas alfa. Nos detritos resultantes desse experimento eles registraram sinais que correspondiam, segundo os pesquisadores, ao elemento $\mathrm{Z}=61$. $\mathrm{O}$ grupo chegou inclusive a propor o nome ciclônio para esse elemento, o que não foi aceito pela comunidade científica em função da falta de prova definitiva da existência desse elemento. ${ }^{41}$

A descoberta do elemento 61 se deu, de forma inequívoca, em 1945, com o trabalho dos químicos americanos Jacob Akiba Marinsky (1918-2005) e Lawrence Elgin Glendenin (1918-2008). Esses pesquisadores trabalhavam no Laboratório Clinton, realizando pesquisas sobre espécies radioativas resultantes da fissão do urânio, para o projeto Manhattan..$^{45}$ Os detalhes da pesquisa foram somente publicados em 1947, ${ }^{46}$ quando eles conseguiram, com o emprego de cromatografia de troca iônica, separar os isótopos do elemento 61 com massas atômicas 147 e 149. Nesse artigo os autores ainda não haviam nomeado o elemento 61 , sempre se referindo a ele pelo seu número atômico. Originalmente o nome Prometeu (da mitologia grega) foi proposto pela esposa de um dos pesquisadores envolvidos na descoberta, entretanto a grafia foi posteriormente alterada para Promécio para harmonizar com a dos demais metais. ${ }^{47}$

Todos os isótopos do promécio são radioativos, sendo que o mais estável $\left({ }^{145} \mathrm{Pm}\right)$ apresenta tempo de meia-vida de 17,7 anos, enquanto para ${ }^{149} \mathrm{Pm}$ esse valor é de apenas 41 horas, embora esse valor tenha sido alterado posteriormente. ${ }^{46} \mathrm{~A}$ instabilidade do promécio foi a causa da grande dificuldade na sua descoberta. Esse elemento ocorre na crosta terrestre em quantidades diminutas, sendo constantemente produzido pela fissão do urânio, e imediatamente decomposto.

A história das terras raras é complexa e difícil de ser contada. Sobre isso, o químico Georges Urbain, um dos que mais trabalhou para esclarecer o problema desse grupo de compostos chegou a dizer que as terras raras são "um mar de erros e a verdade está se afogando nele". ${ }^{48}$

Conforme comentamos, o posicionamento dos elementos terras raras na tabela periódica sempre foi um problema, mesmo para Mendeleev. ${ }^{49}$ Por quase um ano ele tentou posicionar as terras raras conhecidas em sua tabela, mas fracassou. Como ficou evidenciado depois, os elementos "didimium" e érbio eram de fato misturas, como já comentamos. Apesar das dificuldades, Mendeleev não sucumbiu à possibilidade de que seu "sistema periódico" pudesse acomodar exceções.

Em 1902, ainda antes da morte de Mendeleev - ocorrida em 1907 - Brauner apresentou uma versão da tabela periódica em que, pela primeira vez, os lantanídeos (parte das terras raras conhecidas) aparecem agrupados em bloco de quatro colunas e cinco linhas (Figura 19). ${ }^{50}$ Esse bloco foi posicionado logo após o lantânio (La), e terminado com o itérbio (Yb). Embora em 1902 apenas o lutécio e o promécio ainda não haviam sido descobertos, a tabela tinha espaço para acomodar 20 terras raras. Também deve ser notado que o escândio ( $\mathrm{Sc}$ ), ítrio (Y) e o lantânio (La), aparecem no grupo III, com o boro (B) e o alumínio (Al).

Durante muito tempo, várias outras propostas de posicionamento das terras raras na Tabela Periódica foram feitas, a sua maioria agrupando esses elementos em um bloco separado do corpo principal. Nas 
Periodisohes Bystem der Elemente (volle Gestalt).

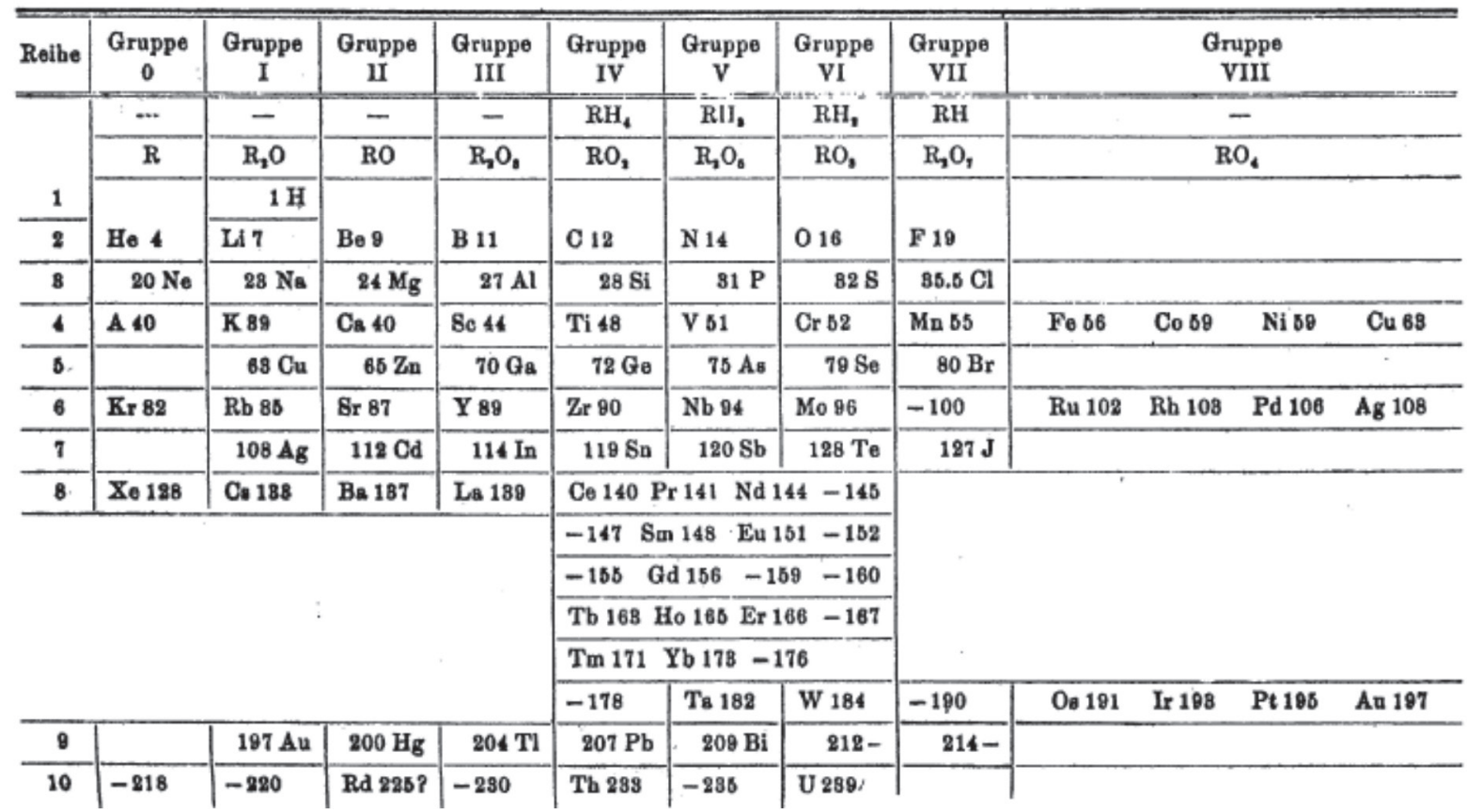

Figura 19. Tabela periódica, com destaque para a posição dos lantanídeos agrupados fora do corpo principal dos oito grupos ${ }^{50}$

tabelas atuais o escândio e o ítrio aparecem na coluna 3. No espaço logo abaixo do ítrio é representado o símbolo $\mathrm{La}-\mathrm{Lu}$, indicando que do lantânio ao lutécio, todos têm propriedades muito parecidas que justifiquem o posicionamento na coluna 3. A tabela é então complementada listando-se os lantanídeos em uma linha separada do seu corpo..$^{51}$

É importante mencionar que as terras raras foram descobertas no Brasil ainda no século XIX, em areias monazíticas nas praias do Prado, no sul da Bahia. Grande quantidade dessa areia foi enviada para a Europa e Estados Unidos, no final do século XIX, supostamente como lastro de navios, sem que fosse paga qualquer quantia por esse material. ${ }^{44}$ Parte das pesquisas realizadas por von Welsbach sobre terras raras, foi conduzida com material obtido de praias brasileiras.

Embora as terras raras tenham sido finalmente posicionadas na Tabela Periódica, até as décadas de 1940-1950 elas tinham poucas aplicações. Esse cenário mudou a partir de 1947, com a criação do Laboratório Ames, nos Estados Unidos, sob a liderança de Frank Harold Spedding (1902-1984). A partir do desenvolvimento de métodos de separação pela equipe de Spedding esses elementos passaram a ser disponíveis em quantidades necessárias para estudos de suas propriedades químicas e físicas. As aplicações das terras raras são diversas e englobam a fabricação de materiais como: ligas para baterias, luminóforos, catalisadores para craqueamento de petróleo, vidros, polímeros, lasers, magnetos, fibras opticas etc. ${ }^{44,52}$ Produtos que dependem das terras raras incluem telefones celulares, telas de televisão, carros elétricos, turbinas para geração de energia eólica, magnetos de alto desempenho, por exemplo. Em função da demanda crescente por esses elementos, a procura por novas fontes é uma prioridade em países como os Estados Unidos. ${ }^{53}$

Há alguns anos surgiu uma polêmica em português a respeito da melhor denominação dos elementos compreendidos do lantânio ao lutécio, que tradicionalmente eram denominados lantanídeos. Sugeriu-se, então, a mudança para lantanoides como designação genérica desses elementos. Todavia, em português não existe a hipótese de confusão da desinência ídeos com o que ocorre em inglês com a desinência ides, característica de alguns íons negativos naquela língua. Portanto, não se justifica a necessidade de mudar o nome dos lantanídeos para lantanoides.

\section{OS ELEMENTOS RADIOATIVOS NATURAIS E OS NOVOS ELEMENTOS DESCOBERTOS NO SÉCULO XX}

É bem conhecida a história da descoberta da radioatividade, a partir de sais de urânio e tório, que deu ao casal Pierre Curie (1859-1906) e Marie Curie (1867-1934), junto com Antoine Henri Becquerel (1852-1908), o Prêmio Nobel de Física de 1903. A palavra radioatividade foi cunhada por Marie Curie em 1898. Em seus estudos com a pechblenda, um resíduo da produção de urânio, ela conseguiu isolar dois novos elementos, o polônio e o rádio, no mesmo ano de 1898, ambos muito mais radioativos que o urânio. O rádio, mesmo em forma ainda impura, era um milhão de vezes mais ativo que o urânio. ${ }^{54}$

Este trabalho abriu as portas para um enorme e fértil campo de pesquisa, a busca por novos elementos que apresentassem radioatividade. A partir daí se descobriram os isótopos e as chamadas "emanações", as emissões de partículas radioativas cujo estudo revolucionou tanto a química como a física nas décadas seguintes.

O número de elementos e isótopos conhecidos logo cresceu exponencialmente, a partir de exemplos como ${ }^{235} \mathrm{U}$ e ${ }^{238} \mathrm{U}$. O tempo de meia-vida desses isótopos é muito variável, assim como sua radioatividade. O estanho é notável por ser o elemento com o maior número de isótopos estáveis (não-radioativos), 10 no total, além de mais dois isótopos radioativos. ${ }^{55} \mathrm{~A}$ descoberta de elementos com o advento dos estudos com materiais radioativos cresceu enormemente no início do século XX, mas sua descoberta por meios puramente químicos cessou após 1925, com a descoberta do rênio.

Em 1923, o holandês Dirk Coster (1889-1950) e o húngaro George Charles de Hevesy (1885-1966), trabalhando na Dinamarca, descobriram um novo elemento, de número atômico 72, o háfnio, de existência prevista por Mendeleev. O nome do elemento foi dado em homenagem à cidade de Copenhagen, a partir de seu nome latinizado, Hafnia. Mendeleev, embora sugerisse que o novo elemento fosse um análogo do titânio e do zircônio, o havia colocado abaixo 
do zircônio, ignorando a existência dos lantanídeos, que ainda não eram conhecidos. ${ }^{56}$

A descoberta do rênio ocorreu em 1925, por Walter Noddack (1893-1960), Ida Tacke (1896-1978) e Otto Berg (1873-1939)..$^{55}$ O rênio é um metal raríssimo, obtido a partir de amostras de molibdênio, e sua concentração na crosta terrestre é da ordem de poucos ppb's. ${ }^{57}$ O metal, cujo nome deriva do Rio Reno, havia sido previsto por Mendeleev como dvi-manganês.

O último elemento natural descoberto, embora altamente radioativo, foi o frâncio, por Marguerite Perey (1909-1975), uma ex-aluna de Marie Curie, em 1939. ${ }^{56}$ Antes ele já era referido como eka-césio, após as previsões originais de Mendeleev. Estima-se que existam na crosta terrestre entre 20 e $30 \mathrm{~g}$ de frâncio, e a maior quantidade já obtida foi de cerca de 300.000 átomos. Portanto, nunca se viu uma amostra macroscópica de frâncio, que se supõe altamente reativo, como seus homólogos alcalinos..$^{58}$

Antes do háfnio (1923), do rênio (1925) e do frâncio (1939), haviam sido descobertos no século XX apenas dois outros elementos naturais, da nova classe dos lantanídeos: o európio, descoberto em 1901 por Eugène-Anatole Demarçay (1852-1903) a partir de amostras de samário, e o lutécio, descoberto em 1907 independentemente pelo francês Georges Urbain (1872-1938), o austríaco Carl Auer von Welsbach (1858-1929) e o inglês Charles James (1880-1928). O nome do elemento veio do nome latino da cidade de Paris, Lutécia. ${ }^{59}$

Após 1925 todos os novos elementos eram radioativos, desde o mais leve, o raríssimo tecnécio, previsto por Mendeleev como eka-manganês, e descoberto pelos italianos Emilio Gino Segré (1905-1989) e Carlo Perrier (1886-1948) em 1937. Anteriormente, em 1925, os alemães Ida Tacke, Walter Noddack e Otto Berg, descobridores do rênio, haviam relatado a descoberta do elemento 43 a partir de estudos espectroscópicos de concentrados de rênio, e o denominaram masúrio, a partir da região chamada Masurenland, na Prússia Oriental. Contudo, seus resultados não foram considerados conclusivos, e a descoberta do elemento 43 , renomeado tecnécio só veio a ser comprovada em $1937 .{ }^{60}$ Como se pode perceber, havia uma boa dose de nacionalismo em muitos dos nomes que se davam aos elementos descobertos na época. O tecnécio é o elemento mais leve existente em que todos os isótopos são radioativos. ${ }^{60}$

\section{HENRY MOSELEY E O CONCEITO DE NÚMERO ATÔMICO}

A Tabela de Mendeleev, não-obstante seus méritos, tinha um inconveniente, pois agrupava os elementos pela ordem crescente de pesos atômicos, hoje massas atômicas relativas. Havia aquelas inversões já mencionadas, como entre Co e Ni. Com a descoberta dos isótopos, a situação ficou pior: como ordenar os elementos na tabela e qual isótopo devia ser preferido? Pondo-se uma média ponderada dos pesos atômicos, como se fazia, o resultado refletia a situação relativa aos isótopos já conhecidos. Havia, porém, a possibilidade de se descobrirem mais isótopos, o que podia alterar a média.

Henry Gwyn Jeffreys Moseley (1887-1915), que havia trabalhado na Universidade de Manchester sob a orientação de Ernest Rutherford, executou, já em Oxford, em 1913, um experimento pelo qual bombardeou um grande número de elementos com elétrons de alta energia, o que produzia a emissão de raios X. Em seguida estabeleceu um gráfico, pondo a sequência dos elementos na Tabela Periódica contra a frequência dos raios $\mathrm{X}$ emitidos pelo bombardeio dos elementos com os elétrons.

As energias dos raios $\mathrm{X}$ emitidos pelos átomos bombardeados dependia de cada átomo, variando então com o elemento.

Como se pode ver no gráfico mostrado na Figura 20, a ordem do elemento na Tabela contra a raiz quadrada da frequência dos
raios-X emitidos resulta numa reta. Isto evidenciou que a sequência dos elementos na Tabela Periódica é uma propriedade muito mais fundamental que sua massa. Moseley chamou à sequência obtida de números atômicos.

Com a descoberta de Moseley, os elementos passaram a ser descritos na ordem de seus números atômicos, e não de seus pesos atômicos. Assim foram eliminadas as incongruências da Tabela de Mendeleev.

Como um post-scriptum, vale dizer que Henry Moseley apresentou-se como voluntário no exército britânico para lutar na Grande Guerra de 1914 e morreu em 1915 vitimado por uma bala turca na Batalha de Gallipoli, no Estreito de Dardanelos, aos 28 anos. ${ }^{61}$

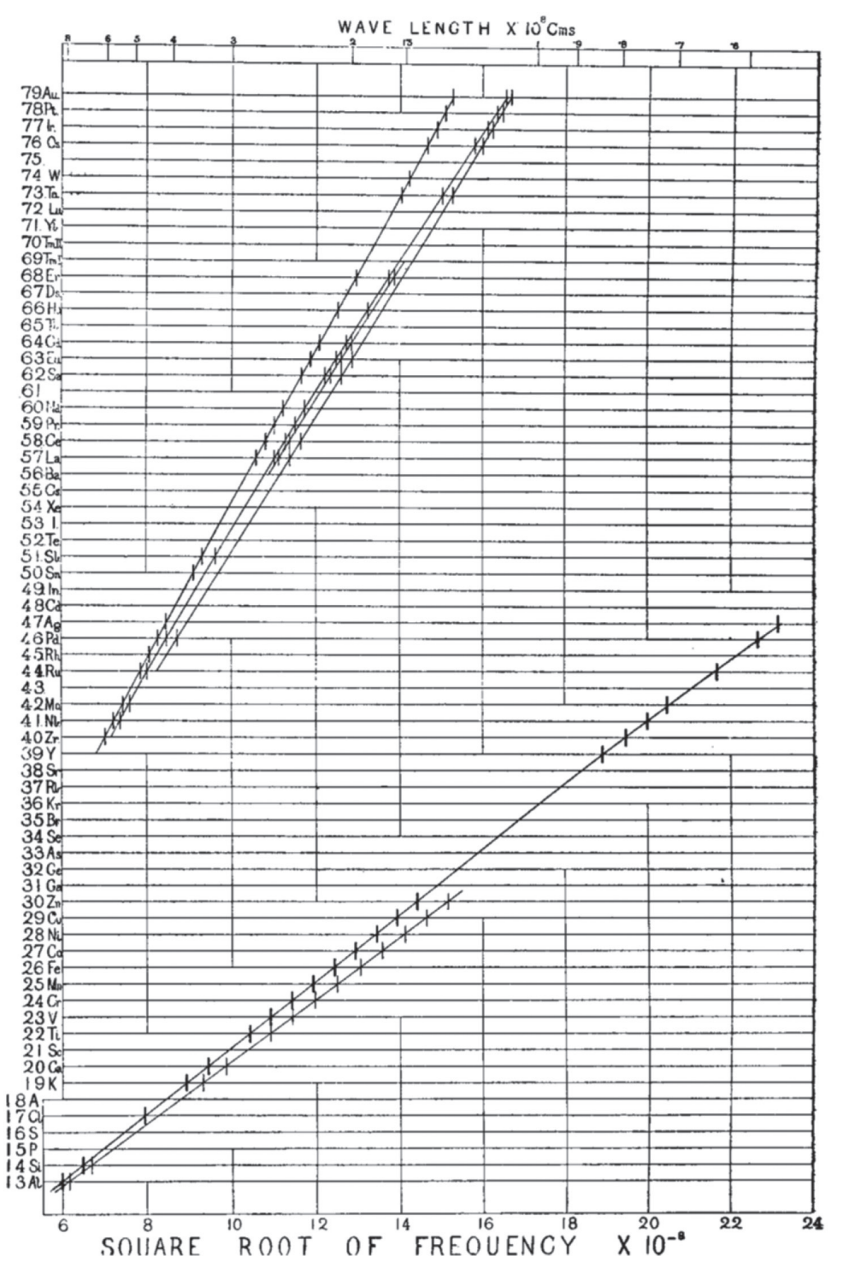

Figura 20. O gráfico de Moseley, relacionando a sequência dos elementos na Tabela Periódica, denominada por ele de sequência de números atômicos, contra um parâmetro relacionado à raiz quadrada da frequência dos raios $X$ para cada elemento ${ }^{62}$

\section{O SONHO DOS ALQUIMISTAS: A TRANSMUTAÇÃO DOS ELEMENTOS}

\section{A transmutação natural por decaimento radioativo}

No início de sua carreira, depois de trabalhar em Cambridge com Joseph John Thomson (1856-1940), Ernest Rutherford (18711937) passou 9 anos na Universidade McGill, em Montreal. Lá ele e Frederick Soddy (1877-1956), em 1900-1903 estudaram as "emanações" do tório. Soddy sugeriu que o tório originava um gás inerte (radônio). Em 1903 publicaram a "Lei de Transformação Radioativa", mostrando que a desintegração produzia átomos mais leves a partir de átomos pesados em consequência de emissão alfa. ${ }^{63}$ 
Os elementos de Lavoisier caíam, e a busca dos alquimistas pela transmutação de um elemento em outro mostrava-se possível. Rutherford ganhou o Prêmio Nobel de Química (1908) pelo estudo da desintegração e da química de substâncias radioativas. Soddy o ganhou em 1921, pelos isótopos, termo por ele cunhado em 1913. Sua explicação para a existência de isótopos resolveu o problema de colocar na Tabela Periódica os inúmeros novos "elementos" (i.e., isótopos).

\section{A transmutação artificial dos elementos}

A primeira transmutação artificial foi conseguida em 1925 pelo assistente de Rutherford, Patrick Maynard Stuart Blackett (18971974), com a transmutação de nitrogênio em oxigênio, por meio da incidência de partículas alfa sobre o nitrogênio-14: ${ }^{64}$

$$
{ }^{14} \mathrm{~N}+\alpha \rightarrow{ }^{17} \mathrm{O}+\mathrm{p}
$$

Em 1932, 2 colegas de Rutherford, John Douglas Cockcroft (1897-1967) e Ernest Thomas Sinton Walton (1903-1995) usaram prótons acelerados sobre ${ }^{7} \mathrm{Li}$ para dividir este núcleo, com a formação de duas partículas $\alpha$. $^{65}$

Esta reação, embora de natureza diferente, precedeu a fissão nuclear, a ser descoberta em 1938 por Otto Hahn (1879-1968), Lise Meitner (1878-1968) e seu assistente Friedrich Wilhelm "Fritz" Strassmann (1902-1980), com átomos pesados, que veio a constituir o processo que ocorre em reatores e explosões nucleares. ${ }^{65}$

\section{ELEMENTOS TRANSURÂNICOS E SUPERPESADOS}

Nem todos os elementos químicos discriminados na tabela periódica possuem núcleos estáveis. À medida que o número de prótons aumenta, cresce também a repulsão eletrostática e a possibilidade de ocorrer o fenômeno denominado desintegração radioativa. Essa degradação ocorrerá, por milênios ou milissegundos, dependendo da espécie, até que o elemento se transforme em outro que seja estável. Foi graças a essa instabilidade nuclear, detectada no final séc. XIX, que se descobriu o fenômeno de radioatividade em 1896, provando que átomos não são indivisíveis, como previa o modelo atômico de Dalton. Do hidrogênio ao urânio, poucos elementos são radioativos e parte deles é encontrada na natureza, tecnécio ( $\mathrm{Tc}$ ), polônio (Po), astato (At), radônio $(\mathrm{Rn})$, frâncio $(\mathrm{Fr})$, rádio $(\mathrm{Ra})$, actínio $(\mathrm{Ac})$, tório $(\mathrm{Th})$, protactínio $(\mathrm{Pa})$ e urânio $(\mathrm{U})$. Desses elementos merecem destaque aqueles que foram inicialmente preparados e anos depois encontrados na natureza. $\mathrm{O}$ tecnécio foi o primeiro elemento preparado artificialmente e descoberto por obra do acaso. Como dito anteriormente, ele foi detectado por Carlo Perrier (1886-1948) e Emilio Segrè (1905-1989) da Universidade de Palermo em amostras de molibdênio irradiadas no cíclotron de Berkeley em 1937. Em 1982 ele foi detectado em amostras de pechblenda, como produto da fissão do ${ }^{238} \mathrm{U}$. O astato é outro elemento sintético, inicialmente preparado em 1940 no Lawrence National Radiation Laboratory (chamado Lawrence Berkeley National Laboratory nos dias atuais) ${ }^{66}$ da Universidade da Califórnia em Berkeley, e depois descoberto em minerais contendo urânio e tório. Ele é considerado um dos elementos mais raros na terra, cuja concentração é estimada em alguns poucos gramas na crosta terrestre. O radônio é originado do decaimento do rádio, portanto pode ser encontrado em determinados lugares onde existam minerais de $\mathrm{Ra}$, a despeito de sua baixa meia-vida, menor que quatro dias.

Em 1896, o físico francês Antoine Henri Becquerel (1852-1908), trabalhando com materiais fosforescentes, suspeitou que o brilho provocado por eles poderia ser fosforescência. Becquerel colocou então vários materiais que exibiam essa propriedade nas proximidades de chapas fotográficas com um anteparo feito de papel preto. As chapas foram danificadas na presença de minerais contendo urânio. Suspeitou-se que esses materiais emitiam um certo tipo de radiação, chamada de raios de Becquerel. Pensou-se inicialmente que essas "emanações" eram raios-X, mas muito cedo percebeu-se tratar-se de uma forma diferente de radiação. Os trabalhos futuros de Rutherford, Paul Ulrich Villard (1860-1934), Kazimierz Fajans (1887-1975) e Soddy demonstraram ser um tipo de radiação mais energética que os raios-X, denominada radiação gama, no caso do rádio, ou de partículas, chamadas alfa e beta, oriundas do núcleo do urânio. Pesquisas posteriores levaram Rutherford e Soddy a entender várias propriedades interessantes desse processo, denominado radioatividade por Marie Curie (1867-1934) e Pierre Curie (1859-1906), descobridores dos elementos rádio e polônio. Observou-se que ocorria um fenômeno chamado decaimento radioativo nos núcleos desses elementos, que se transformavam em outros elementos.$^{67}$ Nos anos seguintes concluiu-se que existem dois tipos de radioatividade, a natural, emanada de minerais contendo elementos radioativos, e a artificial, provocada ao se bombardearem átomos de alguns elementos com partículas alfa ou com elementos mais leves. Este fenômeno foi descoberto por Irène Joliot-Curie (1897-1956) ao bombardear alumínio com partículas alfa, produzindo um isótopo instável de fósforo, ${ }^{30} \mathrm{P}$. Essa pesquisa abriu caminho para a descoberta da fissão nuclear anos depois. Marie Curie faleceu pouco antes de sua filha e genro, Frédéric Joliot-Curie, serem agraciados com o prêmio Nobel de Química em 1935 por essa descoberta. Caso tivesse vivido por mais dois anos, é possível que ela teria compartilhado esse prêmio, tornando-se o cientista com o maior número de prêmios Nobel recebidos. Embora isso não tenha ocorrido, destacam-se os feitos importantes da família Curie.

Os elementos transurânicos são aqueles com mais de 92 prótons, e dentro desse grupo destacam-se os elementos superpesados, que não podem ser obtidos através de bombardeamento de outros elementos mais leves com nêutrons, normalmente com Z $>104 .{ }^{68}$ Esses elementos são todos radioativos e foram preparados em laboratórios, seja em reatores nucleares ou em aceleradores de partículas. Alguns de seus isótopos apresentam meias-vidas longas, e podem ser observados em minerais contendo urânio ou detectados em locais onde ocorreram testes com bombas atômicas ou de hidrogênio.

\section{Descobrimento dos elementos transurânicos}

As pesquisas iniciais que culminaram com a descoberta dos primeiros transurânicos foram dominadas por cientistas americanos do Lawrence National Radiation Laboratory, mas anos depois iniciou-se uma grande disputa com o Joint Institute for Nuclear Research em Dubna, na Rússia. ${ }^{69}$ É interessante notar que embora a execução do projeto Manhattan tenha culminado com a construção das bombas atômicas que aniquilaram Hiroshima e Nagasaki em 1945, o esforço dos pesquisadores envolvidos contribuiu para a descoberta de novos elementos. Dentre os americanos destacou-se o grupo de pesquisa de Glenn Theodore Seaborg (1912-1999), dentre outros. Já os russos foram liderados inicialmente por Georgy Nikolayevich Flerov (1913-1990).

Os primeiros transurânicos, $\mathrm{Np}(\mathrm{Z}=93)$ e $\mathrm{Pu}(\mathrm{Z}=94)$, foram nomeados em referência aos planetas Netuno e Plutão, exteriores a Urano, nome do elemento com $Z=92$. Aqueles dois elementos foram encontrados na natureza anos depois de suas preparações iniciais de 1940, sendo ${ }^{237} \mathrm{~Np} \mathrm{e}{ }^{244} \mathrm{Pu}$ seus isótopos mais estáveis (Tabela I). O netúnio foi preparado no grupo de Edwin Mattison McMillan (1907-1991) ao se irradiar ${ }^{238} \mathrm{U}$ com nêutrons, enquanto o plutônio foi produzido no grupo de Seaborg por bombardeamento do ${ }^{238} \mathrm{U}$ com deutério. ${ }^{70,71}$ Seaborg fez também uma exaustiva caracterização química do $\mathrm{Pu}$, 
e seu grupo identificou em 1944 o amerício (Am, $Z$ =95) e o cúrio $(\mathrm{Cm}, \mathrm{Z}=96)$, oriundos do bombardeamento de ${ }^{238} \mathrm{U}$ com nêutrons. ${ }^{72}$ $\mathrm{O}$ cúrio pôde também ser produzido através do bombardeamento de ${ }^{239} \mathrm{Pu}$ com partículas alfa. O nome amerício foi dado em homenagem à América, em analogia ao európio que se localiza acima na tabela periódica, cujo nome homenageou o continente europeu. Já o cúrio foi nomeado em honra de Pierre e Marie Curie..$^{73}{ }^{241} \mathrm{Am}$ e ${ }^{243} \mathrm{Am}$ são os isótopos com maior tempo de vida do amerício, enquanto os do cúrio são ${ }^{247} \mathrm{Cm}$ e ${ }^{248} \mathrm{Cm}$ (Tabela 1). É importante notar que os valores dos tempos de meia vida dos elementos da Tabela 1 costumam variar de acordo com as referências consultadas, de modo que os valores aqui apresentados devem ser considerados os mais prováveis para uma série de fontes consultadas, como aquelas citadas neste parágrafo.

Tabela 1. Tempos de meia-vida dos isótopos mais estáveis de elementos transurânicos

\begin{tabular}{cccc}
\hline Isótopo & Meia-vida & Isótopo & Meia-vida \\
\hline${ }^{237} \mathrm{~Np}$ & $2 \times 10^{6}$ anos & ${ }^{267} \mathrm{Rf}$ & $1,3 \mathrm{~h}$ \\
${ }^{244} \mathrm{Pu}$ & $8 \times 10^{7}$ anos & ${ }^{268} \mathrm{Db}$ & $28 \mathrm{~h}$ \\
${ }^{241} \mathrm{Am}$ & 432 dias & ${ }^{269} \mathrm{Sg}$ & $14 \mathrm{~min}$ \\
${ }^{243} \mathrm{Am}$ & 7370 anos & ${ }^{271} \mathrm{Bh}$ & $1,2 \mathrm{~min}$ \\
${ }^{247} \mathrm{Cm}$ & $1,56 \times 10^{7}$ anos & ${ }^{270} \mathrm{Hs}$ & $10 \mathrm{~s}$ \\
${ }^{248} \mathrm{Cm}$ & $3,5 \times 10^{5}$ anos & ${ }^{282} \mathrm{Mt}$ & $67 \mathrm{~s}$ \\
${ }^{247} \mathrm{Bk}$ & 1380 anos & ${ }^{281} \mathrm{Ds}$ & $9,1 \mathrm{~s}$ \\
${ }^{252} \mathrm{Cf}$ & 2645 anos & ${ }^{282} \mathrm{Rg}$ & $100 \mathrm{~s}$ \\
${ }^{252} \mathrm{Es}$ & 471,7 dias & ${ }^{286} \mathrm{Cn}$ & $8.45 \mathrm{~s}$ \\
${ }^{257} \mathrm{Fm}$ & 100 dias & ${ }^{286} \mathrm{Nh}$ & $10 \mathrm{~s}$ \\
${ }^{262} \mathrm{Lr}$ & $3,6 \mathrm{~h}$ & ${ }^{290} \mathrm{Fl}$ & $19 \mathrm{~s}$ \\
${ }^{266} \mathrm{Lr}$ & $11 \mathrm{~h}$ & ${ }^{290} \mathrm{Mc}$ & $0,7 \mathrm{~s}$ \\
& & ${ }^{293} \mathrm{Lv}$ & $60 \mathrm{~ms}$ \\
& & ${ }^{294} \mathrm{Ts}$ & $78 \mathrm{~ms}$ \\
& & ${ }^{294} \mathrm{Og}$ & $0,89 \mathrm{~ms}$ \\
\hline
\end{tabular}

A descoberta desses elementos sintéticos foi um passo importante para a preparação em Berkeley de novos transurânicos, oriundos de investigações dos grupos de pesquisa de Seaborg ou Albert Ghiorso (1915 - 2010). Todos esses elementos possuem meias-vidas de anos ou dias (Tabela I). O berquélio (Bk, Z=97), obtido em 1949 pelo bombardeamento de ${ }^{241} \mathrm{Am}$ com partículas alfa, homenageou a cidade de Berkeley. ${ }^{74}$ Em seguida o estado americano da Califórnia foi a origem do nome do califórnio (Cf, $\mathrm{Z}=98$ ), preparado em 1950, pelo bombardeamento de ${ }^{242} \mathrm{Cm}$ com partículas alfa.

Antes de suas preparações, o einstênio (Es, Z=99) e o férmio (Fm, $\mathrm{Z}=100$ ) foram detectados em $1952 \mathrm{em}$ locais de testes com bombas de hidrogênio, sendo em seguida produzidos em quantidades pequenas em reatores nucleares; no caso do Es, através da reação nuclear entre ${ }^{14} \mathrm{~N} \mathrm{e}{ }^{238} \mathrm{U}$ ou do decaimento do ${ }^{253} \mathrm{Cf}$, e do Fm pelo bombardeamento do ${ }^{238} \mathrm{U}$ com nêutrons. Estes elementos renderam homenagem a Albert Einstein (1979-1955) e Enrico Fermi (1901-1954). ${ }^{75}$

O elemento 101, mendelévio (Md, Z=101) foi preparado em 1955 pelo bombardeamento do ${ }^{253} \mathrm{Es}$ com partículas alfa no cíclotron de Berkeley. Devido à guerra fria, Seaborg teve de solicitar autorização ao governo americano para homenagear Dmitri Mendeleev, ao dar o nome de um russo a esse novo elemento. ${ }^{76}$

O férmio é o elemento mais pesado a ser obtido por bombardeamento de actinídeos com nêutrons. Para se obter elementos com Z>100 foi necessário efetuar o bombardeamento de elementos alvos com íons. Uma característica interessante é a existência fugaz desses elementos pesados, o que dificultou bastante a caracterização e validação dos resultados. Outra questão que envolveu as pesquisas da década de 1950 ao início da década de 1980, foi a acirrada disputa entre soviéticos e americanos, que precisou ser mediada pela IUPAC. A descoberta do nobélio, (No, Z=102), nome dado em referência a Alfred Nobel (1833-1896), foi creditada em 1997 pela IUPAC aos soviéticos, que efetuaram em 1966 a fusão nuclear do ${ }^{238} \mathrm{U}$ com íons de neônio em Dubna. Os americanos, liderados por Seaborg, relataram em 1958 a preparação desse elemento usando um novo acelerador da Universidade da Califórnia em Berkeley, por bombardeamento de mistura de isótopos de cúrio, composta por $95 \%$ de ${ }^{244} \mathrm{Cm}$ e $5 \%$ ${ }^{246} \mathrm{Cm}$ ) com íons de ${ }^{13} \mathrm{C}$ e ${ }^{12} \mathrm{C}$. Entretanto, houve questões não apropriadamente respondidas por esses pesquisadores. A IUPAC acatou a sugestão de nome feita por suecos, que chegaram a descrever a preparação desse novo elemento na década de $1950 .{ }^{77}$

O laurêncio ( $\mathrm{Lr}, \mathrm{Z}=103$ ) é o último dos actinídeos. Novamente, devido a sua curta existência e dificuldade em caracterizar seus decaimentos de forma segura, a acirrada disputa entre americanos e soviéticos continuou. Seus isótopos mais estáveis são ${ }^{262} \mathrm{Lr}$ e ${ }^{266} \mathrm{Lr}$. A IUPAC inicialmente atribuiu sua descoberta aos americanos, tendo até aceitado o nome em honra de Ernest Orlando Lawrence (1901-1958), inventor do acelerador de partículas. Mas em 1997 o caso foi reavaliado e sua descoberta foi atribuída a ambos os grupos de pesquisadores, soviéticos e americanos. O grupo americano do Lawrence Berkeley National Laboratory, liderado por Ghiorso, obteve este elemento ao bombardear ${ }^{248} \mathrm{Cm}$ com íons de ${ }^{14} \mathrm{~N}$, ou ${ }^{252} \mathrm{Cf}$ com diferentes isótopos de boro $\left({ }^{10} \mathrm{~B}\right.$ ou $\left.{ }^{11} \mathrm{~B}\right)$. Já o grupo russo efetuou a fusão de ${ }^{243} \mathrm{Am}$ com ${ }^{18} \mathrm{O}$.

Os elementos de número atômico 104 a 118 completaram o sétimo período da tabela periódica, indo do eka-háfnio ao eka-radônio. Eles são denominados elementos artificiais superpesados, e são constituídos por vários isótopos, todos com meias-vidas bastante curtas. $\mathrm{O}$ primeiro deles, o rutherfórdio (Rf, Z=104), foi detectado em 1964 pelos soviéticos em Dubna, ao bombardearem ${ }^{242} \mathrm{Pu}$ com ${ }^{22} \mathrm{Ne}$. Em 1969, pesquisadores da Universidade da Califórnia sintetizaram esse mesmo elemento fazendo a fusão nuclear do ${ }^{249} \mathrm{Cf}$ com ${ }^{12} \mathrm{C}$. Os soviéticos propuseram o nome de kurchatóvio em honra de Igor Vasilyevich Kurchatov (1903-1960), um dos fundadores do grupo soviético de pesquisa, enquanto os americanos chamaram-no de rutherfórdio em homenagem a Ernest Rutherford. Em 1997 ambos os grupos de pesquisa concordaram em chamá-lo de rutherfórdio (Rf). ${ }^{77}$

Os soviéticos coordenados por Flerov prepararam o elemento 105 pela primeira vez em 1968 por bombardeamento de ${ }^{243} \mathrm{Am}$ com ${ }^{22} \mathrm{Ne}$. Dois anos depois, pesquisadores da Universidade da Califórnia relataram sua obtenção pelo bombardeamento de ${ }^{249} \mathrm{Cf} \operatorname{com}{ }^{15} \mathrm{~N}$. A proposta de nome para este elemento fez parte da mesma controvérsia envolvendo a descoberta do Rf. Houve várias propostas de nomes, sendo ele inicialmente chamado de nielsbóhrio (Ns) pelos soviéticos, em homenagem a Niels Bohr (1885-1962), ou hahnium pelos americanos em honra de Otto Hahn. Em 1997 a IUPAC chegou a um consenso em relação aos elementos de número atômico 104 a 106. O novo elemento 105 recebeu o nome de dúbnio em referência à cidade russa onde se localiza o Joint Institute for Nuclear Research. ${ }^{78}$

A descoberta do seabórgio (Sg, Z=106) foi anunciada em 1970 por Ghiorso, sendo confirmada apenas em 1974, como produto da reação nuclear entre ${ }^{249} \mathrm{Cf} \mathrm{e}{ }^{18} \mathrm{O}$. Nesse ano os soviéticos de Dubna, liderados por Yuri Tsolakovich Oganessian (1933- ), também anunciaram sua preparação, o que manteve a disputa com os americanos. A sugestão do nome searbórgio foi feita pelos americanos, em homenagem a Seaborg, sendo apenas ratificada pela IUPAC em 1997, que creditou sua descoberta a ambos os grupos. ${ }^{79}$ Até essa data adotou-se o padrão de nomenclatura de novos elementos químicos, chamando-o de unnilhexio. ${ }^{80}$ 
A preparação de novos elementos artificiais na década de 1980 foi marcada positivamente pelo surgimento de grupos de pesquisas em física ou química nuclear fora dos Estados Unidos da América ou da União Soviética. O bóhrio $(\mathrm{Bh}, \mathrm{Z}=107)$ havia sido anunciado pelo grupo de pesquisa de Dubna em 1976, liderado por Oganessian, como resultado da reação nuclear entre ${ }^{209} \mathrm{Bi} \mathrm{e}{ }^{54} \mathrm{Cr}$ ou entre ${ }^{208} \mathrm{~Pb}$ com ${ }^{55} \mathrm{Mn}$. O mesmo elemento foi anunciado em 1981 pela Gesellschaft für Schwerionenforschung (GSI) (hoje Helmholtzzentrum für Schwerionenforschung), em Darmstadt, na Alemanha, liderados por Peter Armbruster (1931- ) e Gottfried Münzenberg (1940- ). ${ }^{81,82}$ Os alemães sugeriram o nome nielsbóhrio em 1992, em honra de Niels Bohr, nome aceito pelo grupo de Dubna. ${ }^{83}$ Em 1997 a IUPAC adotou o nome bóhrio.

Em 1978, o grupo de pesquisa de Oganessian tentou preparar o próximo elemento 108 , pela fusão nuclear do ${ }^{226} \mathrm{Ra} c \mathrm{com}^{48} \mathrm{Ca}$, ou entre ${ }^{208} \mathrm{~Pb}$ com ${ }^{58} \mathrm{Fe}$. Outras tentativas se seguiram em 1983 e 1984 , entretanto os resultados obtidos não foram considerados conclusivos pelos próprios pesquisadores russos. ${ }^{77} \mathrm{Em} 1984$, o grupo de pesquisa alemão do GSI relatou a preparação do elemento 108, isolado ao se reproduzir a reação nuclear feita pelos soviéticos entre ${ }^{208} \mathrm{~Pb} c{ }^{2}{ }^{58} \mathrm{Fe}$. Os resultados foram em seguida confirmados pelos pesquisadores de Dubna. ${ }^{84}$ Em 1994 a IUPAC recomendou o nome hahnio para esse novo elemento, em homenagem a Otto Hahn, mas em 1997 adotou-se o nome hássio (Hs), como sugerido pelos alemães, em referência à região de Hesse na Alemanha, local onde se localiza o GSI. ${ }^{85}$

Esse mesmo grupo de pesquisa sintetizou em 1982 o meitnério (Mt, $\mathrm{Z}=109$ ), por reações nucleares de ${ }^{209} \mathrm{Bi}$ com ${ }^{58} \mathrm{Fe}$, cujos resultados foram confirmados três anos depois em Dubna. ${ }^{86} \mathrm{O}$ nome oficial dado a este elemento foi uma merecida homenagem da IUPAC à física austríaca Lise Meitner, que descobriu, junto com Otto Hahn, a fissão nuclear e o elemento protactínio, sendo ignorada na concessão do prêmio Nobel de Química de $1944 .{ }^{87}$ O darmstádtio (Ds, Z=110) foi também produzido em 1994 no GSI na Alemanha por um grupo de pesquisa coordenado por Sigurd Hofmann (1944- ), a partir do bombardeamento ${ }^{208} \mathrm{~Pb}$ com núcleos de ${ }^{62} \mathrm{Ni}$. Seu nome foi dado em referência à cidade alemã de Darmstadt. ${ }^{88}$ Experimentos semelhantes conduzidos na mesma época, mas usando núcleos de ${ }^{64} \mathrm{Ni}$, levaram à formação de 9 átomos desse novo elemento. Resultados de experimentos anteriores em Dubna, com ${ }^{244} \mathrm{Pu}$ e ${ }^{34} \mathrm{~S}$, e em Berkeley, com ${ }^{209} \mathrm{Bi}$ e ${ }^{59} \mathrm{Co}$, sugeriam a existência desse elemento (Ds), mas os resultados não foram conclusivos. A atuação de pesquisadores alemães foi fundamental para o progresso da pesquisa nuclear e para a descoberta de novos elementos químicos. Armbruster e Hoffmann realizaram em 1994 a fusão nuclear do ${ }^{209} \mathrm{Bi}$ com núcleo de ${ }^{64} \mathrm{Ni}$, levando à formação do roentgênio $(\mathrm{Rg}, \mathrm{Z}=111) \cdot{ }^{89} \mathrm{O}$ nome roentgênio foi proposto pelos descobridores alemães em homenagem a Wilhelm Conrad Roentgen (1845-1923), pela descoberta dos raios-X, que lhe deu o primeiro prêmio Nobel de Física da História..$^{90} \mathrm{O}$ copernício ( $\mathrm{Cn}, \mathrm{Z}=111$ ) foi preparado em 1996 no GSI pelo bombardeamento de ${ }^{208} \mathrm{~Pb}$ com ${ }^{70} \mathrm{Zn} .{ }^{91}$ De acordo com recomendações da IUPAC em 2009 recebeu o nome de copernício em honra a Nicolau Copérnico (1473-1543), o grande astrônomo polonês..$^{92}$

Grupos de pesquisas do GSI contribuíram entre 1998-2003 com a descoberta do nihônio ( $\mathrm{Nh}, \mathrm{Z}=113$ ), por fusão nuclear de ${ }^{209} \mathrm{Bi}$ com ${ }^{70} \mathrm{Zn}$. Nesse mesmo período grupo de pesquisa em Dubna, agora composto por americanos e russos, fez reação semelhante entre ${ }^{244} \mathrm{Pu}$ e ${ }^{48} \mathrm{Ca}$. Obteve-se nesse experimento o elemento de $\mathrm{Z}=$ 114 , cujo decaimento imediato formou 1 átomo do elemento de $Z=$ 113. Infelizmente, experimentos posteriores não reproduziram esses resultados. Em 2003 o mesmo grupo de Dubna relatou a formação desse novo elemento, fruto indireto da fusão nuclear de ${ }^{243} \mathrm{Am} \mathrm{e} \mathrm{e}^{48} \mathrm{Ca}$. Finalmente, em 2004 pesquisadores japoneses do Riken, um centro de pesquisa na cidade de Wakõ, liderados por Kōsuke Morita (1957- ) e Hiroshi Matsumoto (1942- ), obtiveram-no diretamente da reação nuclear entre ${ }^{209} \mathrm{Bi} \mathrm{e}{ }^{70} \mathrm{Zn}$. Esses resultados foram confirmados por pesquisadores de diferentes países, EUA, Alemanha, Suécia e China. Pesquisas posteriores confirmaram a existência desse elemento, levando a IUPAC, em 2016, creditar aos japoneses o mérito da descoberta. O nome nihônio dado posteriormente, vem de Nihon, nome do Japão em japonês. ${ }^{93}$ No Ocidente o nome do país é às vezes grafado como Nipon, donde se ter observado também a grafia nipônio para o elemento 113. Como se pode verificar, a obtenção dos elementos mais pesados envolveu o esforço de vários laboratórios na preparação e na identificação dessas espécies bastante fugazes.

Os experimentos nucleares com vários elementos levaram não só à preparação do fleróvio $(\mathrm{Fl}, \mathrm{Z}=114)$ mas dos elementos com Z=113 e 115. Tendo sido reconhecido em 1998, a descoberta do Fl foi atribuída ao grupo de pesquisa de Dubna, conduzido por Oganessian pelo bombardeamento de ${ }^{244} \mathrm{Pu}$ e ${ }^{48} \mathrm{Ca}$, resultados confirmados em 1999. O elemento 114 recebeu da IUPAC o nome fleróvio em homenagem a Flerov, um dos fundadores e coordenador do centro de pesquisa de Dubna durante muitos anos. ${ }^{94}$ Logo em seguida, a fusão nuclear entre ${ }^{243} \mathrm{Am} \mathrm{e}{ }^{48} \mathrm{Ca}$ levou à preparação do moscóvio $(\mathrm{Mc}, \mathrm{Z}=115) .{ }^{95}$ Os resultados anunciados foram confirmados pelos pesquisadores do GSI na Alemanha e da Universidade de Lund na Suécia. O nome moscóvio foi dado em homenagem à região de Moscou, onde se localiza o Joint Institute for Nuclear Research.

Apesar dos esforços de pesquisadores americanos, russos ou alemães, nas décadas de 1980 e 90 em preparar o elemento de número atômico de $\mathrm{Z}=116$ ( $\mathrm{Lv}, \mathrm{Z}=116$ ), ele foi finalmente obtido em Dubna em 2000 em colaboração com americanos do Lawrence Livermore National Laboratory, usando o bombardeamento de alvos de ${ }^{248} \mathrm{Cm}$ com feixes de ${ }^{48} \mathrm{Ca} .{ }^{96}$ Experimentos ocorridos entre 2000 e 2006, realizados por russos, americanos, alemães e japoneses confirmaram os resultados. O nome definitivo foi dado em $2011 \mathrm{em}$ homenagem à cidade americana de Livermore, onde se localiza esse importante centro de pesquisas nucleares. ${ }^{77}$

A preparação do tennesso $(\mathrm{Ts}, \mathrm{Z}=117)$ foi anunciada no ano de 2010 em Dubna, como fruto de experimentos conjuntos de fusão nuclear entre ${ }^{249} \mathrm{Bk} \mathrm{e}{ }^{48} \mathrm{Ca}$, conduzidos por russos e americanos. ${ }^{97} \mathrm{Os}$ dados experimentais obtidos foram reproduzidos anos mais tarde. Vários institutos de pesquisa estiveram envolvidos na descoberta desse novo elemento, Joint Institute of Nuclear Research (Dubna, Rússia), Research Institute for Advanced Reactors (Dimitrovgrad, Rússia), Lawrence Livermore National Laboratory (EUA), Oak Ridge National Laboratory da Universidade Vanderbilt (EUA), GSI (Alemanha), Universidade do Tennessee, Universidade de Nevada (EUA), e Universidade de Lund (Suécia). Destacou-se o trabalho de Joseph H. Hamilton, acadêmico da Universidade Vanderbilt, apontado por Oganessian como o verdadeiro descobridor desse novo elemento. Recebeu em 2016 o nome oficial de tennessine, em inglês, dado em homenagem ao estado americano do Tennessee, onde se localizam as Universidades do Tennessee e Vanderbilt, seguido da desinência típica em inglês para os halogênios, ine.

Existe certo mistério em relação à descoberta do eka-radônio, ou o elemento 118, por se localizar na família dos gases nobres e ser o seu exemplar mais pesado. Em 1922 Niels Bohr já acreditava na existência desse elemento. Anos depois algumas de suas propriedades foram previstas por Aristid von Grosse (1905-1985), químico nuclear alemão radicado nos EUA. ${ }^{98}$ Ele foi finalmente obtido em 2002, em Dubna, por pesquisadores russos e americanos. Seu nome oganessônio ( $\mathrm{Og}, \mathrm{Z}=118$ ), foi dado em honra de Oganessian, cujas contribuições na descoberta dos elementos químicos superpesados foram indiscutíveis. É mais um exemplo de elemento bastante instável, tanto é que em 2005 apenas cinco átomos do isótopo ${ }^{294} \mathrm{Og}$ foram detectados. Suspeitava-se que ele fosse um "gás" em condições normais, 


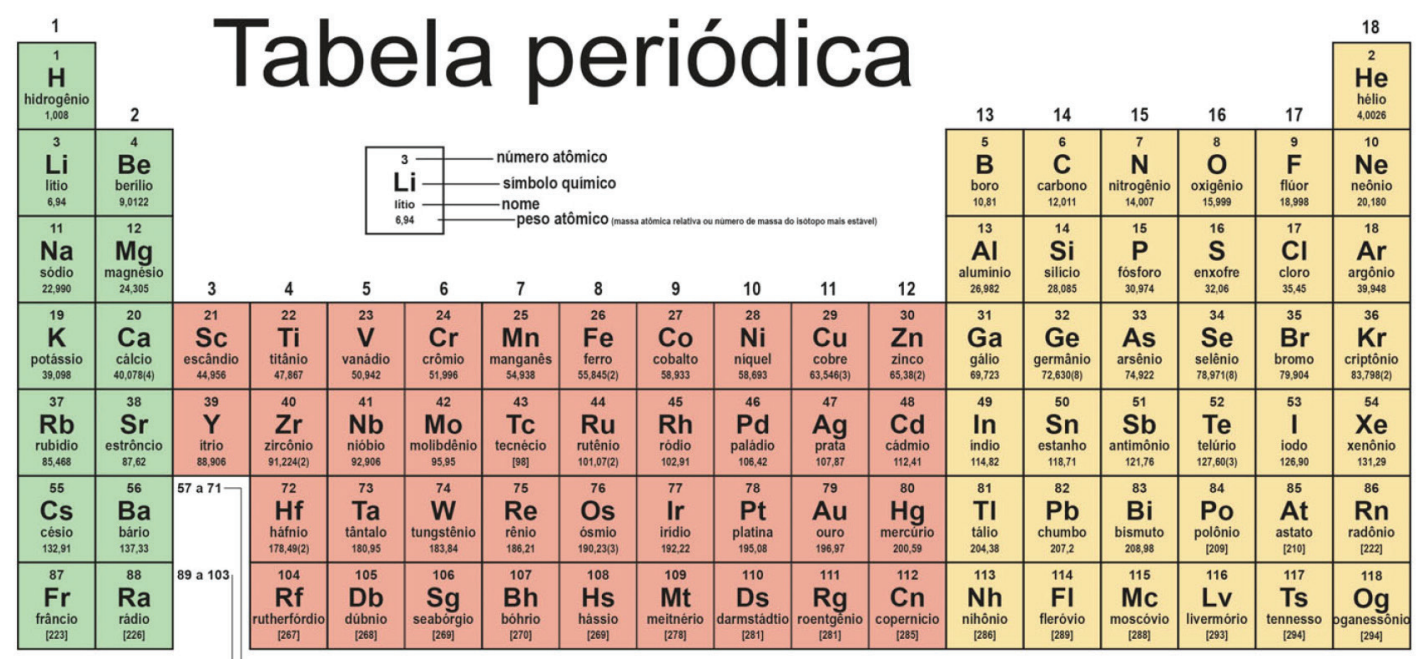

\begin{tabular}{|c|c|c|c|c|c|c|c|c|c|c|c|c|c|c|}
\hline$\underset{\substack{\text { lantânio } \\
138,91}}{\mathbf{L 7}}$ & $\begin{array}{c}58 \\
\mathrm{Ce} \\
\text { cério } \\
140,12\end{array}$ & \begin{tabular}{|c|} 
Praseodimio \\
140,91
\end{tabular} & $\begin{array}{c}\mathbf{6 0} \\
\mathbf{N d} \\
\text { neodimio } \\
144,24\end{array}$ & $\underset{\substack{\text { promécio } \\
\text { [145] }}}{\mathbf{P m}}$ & $\underset{\substack{\text { samário } \\
150,36[2]}}{62}$ & $\underset{\substack{\text { európio } \\
151,96}}{\mathbf{E u}}$ & $\underset{\substack{\text { gadolinio } \\
157,25(3)}}{64}$ & $\begin{array}{c}65 \\
\text { Tb́ } \\
\text { térbio } \\
158,93\end{array}$ & $\begin{array}{c}66 \\
\text { Dy } \\
\text { disprosio } \\
162,50\end{array}$ & $\begin{array}{c}67 \\
\text { Ho } \\
\text { hôlmio } \\
164,93\end{array}$ & $\begin{array}{c}68 \\
\text { Errbio } \\
\text { erbio } \\
167,26\end{array}$ & $\begin{array}{c}69 \\
\text { Tm } \\
\text { túlio } \\
168,93 \\
\end{array}$ & $\begin{array}{c}70 \\
\mathbf{Y b} \\
\text { itérbio } \\
173,05\end{array}$ & 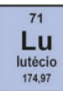 \\
\hline$\underset{\substack{89 \\
\text { actinio } \\
[227]}}{202}$ & $\begin{array}{c}90 \\
\text { Thh } \\
\text { tório } \\
232,04\end{array}$ & 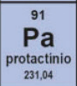 & $\underbrace{92}_{\substack{\text { urânio } \\
288,03}}$ & $\underset{\substack{\text { neptunio }_{[237]} \\
\mathbf{N p}}}{93}$ & $\underset{\substack{94 \\
\text { plutôñio } \\
[244]}}{\mathbf{9 u}}$ & $\underset{\substack{\text { americio } \\
[243]}}{95}$ & $\substack{\text { currio } \\
[247]}^{96}$ & $\underset{\substack{\text { Berquâlio } \\
\text { [247] }}}{97}$ & 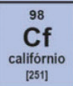 & $\underset{\substack{\text { einstênio } \\
[252]}}{99}$ & 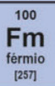 & $\underset{\substack{\text { mendelévio } \\
[285]}}{\mathbf{M} d}$ & $\underset{\substack{\text { Nobellio } \\
\text { [255] }}}{102}$ & 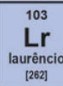 \\
\hline
\end{tabular}
Creative Commons By-NC.SA 4.0 - Use somente para fins educacional

Figura 21. Versão atual da Tabela Periódica IUPAC/SBQ, com 118 elementos

mas devido a efeitos relativísticos acredita-se na possibilidade de que se trate de um sólido. ${ }^{99}$

\section{A TABELA PERIÓDICA ATUAL}

A descoberta de novos elementos, a partir dos anos 1930, começou a deixar de ser uma atividade apenas de químicos para se tornar com o tempo uma atividade tanto de químicos como de físicos de altas energias, trabalhando com fusões de elementos mais leves para obter elementos cada vez mais pesados, até chegar ao número atual de elementos conhecidos, 118, como foi mostrado no texto e pode ser visto na Tabela Periódica moderna, dada na Figura 21.

No dia 13 de julho de 2017, durante a Reunião da IUPAC que coincidiu com a 40 ${ }^{\text {a }}$ Reunião da Sociedade Brasileira de Química, em São Paulo, a IUPAC ratificou os nomes em inglês de quatro novos elementos químicos, que já estavam em uso desde janeiro de 2016, que são, em português, o nipônio $(Z=113)$, o moscóvio $(Z=115)$, o tennesso $(Z=117)$ e o oganessônio $(Z=118) .{ }^{100}$ É curioso lembrar que o elemento 117 é um halogênio. Quanto ao elemento 118, trata-se de um homólogo dos gases nobres, mesmo que seja líquido ou sólido, como se especula. Em Portugal, a Academia das Ciências de Lisboa (ACL) recomendara o nome oganésson (sem a desinência io) em coerência com as terminações dos outros gases nobres naquele país, mas o nome acabou unificado como oganessônio por meio do Livro Verde da IUPAC, acordado pelos dois países.

\section{CONCLUSÃO}

Para finalizar, gostaríamos de enfatizar que aquilo que se sumarizou no Abstract apresentado no início deste texto foi exatamente o que foi perseguido ao longo de todo o artigo, isto é, a aventura da Tabela Periódica pode ser comparada aos dois sentidos de uma larga avenida. No primeiro sentido, a descoberta de elementos levou à necessidade de buscar as relações porventura existentes entre eles, o que foi conseguido depois de já ser conhecido um número razoável deles, ao tempo de Mendeleev. Uma vez estabelecida a Tabela
Periódica, foi ela, por sua vez, que propiciou o tráfego no sentido oposto da avenida, isto é, a busca por preencher suas lacunas serviu de linha diretriz para a pesquisa por elementos ainda não conhecidos.

\section{AGRADECIMENTOS}

Os autores agradecem aos anônimos revisores deste artigo, que, de forma percuciente e detalhada, analisaram todos os aspectos envolvidos no texto e fizeram inúmeras sugestões valiosas que só o enriqueceram. Um agradecimento especial é devido ao Prof. Romeu Cardoso Rocha Filho por inúmeras sugestões importantes.

\section{REFERÊNCIAS E NOTAS}

1. Pendergast, D. M.; Science, 1982, 217, 533.

2. Raymond, R.; Out of the Fiery Furnace - The Impact of Metals on the History of Mankind, The Pennsylvania State University Press, University Park, 1986, pp. 54-55.

3. Id, ibid., pp. 61-62.

4. Ercker, L.; Aula Subterranea, alias Probier Buch Herrn Lazari Erckers, Frankfurt, 1673.

5. Bíblia de Mogúncia; Fust, J., Schoeffer, P., eds.; 1462, 2 volumes, Fundação Biblioteca Nacional.

6. Basilius Valentinus, atrib., Triumphant Chariot of Antimony, London, 1678, edição moderna por Kelly, L. G., ed.; Garland Publishing: New York, 1990.

7. Mendes, J. A.; Governo de Mineiros mui necessário para os que vivem distantes de professores seis, oito, dez e mais léguas, padecendo por esta causa os seus domésticos e escravos queixas que pela dilação dos remédios se fazem incuráveis, e as mais das vezes mortais, Lisboa, 1770; transcrição anotada por Filgueiras, C. A. L., Arquivo Público Mineiro, 2012.

8. Weeks, M. E.; Leicester, H. M.; Discovery of the Elements, Journal of Chemical Education, $7^{\text {th }}$ ed., Easton, 1968, pp. 110-130.

9. Lavoisier, A. L.; Traité Élémentaire de Chimie, Paris, 1789, Tableau des Substances Simples, Tome Premier, p. 192. 
10. Retrato de Lavoisier, desenhado por Jacques-Louis David e gravado por sua mulher Marie-Anne Pierrette Paulze Lavoisier. Oeuvres de Lavoisier, Imprimerie Impériale, Paris, tome premier, 1864.

11. Weeks, M. E.; Leicester, H. M.; Discovery of the Elements, Journal of Chemical Education, $7^{\text {th }}$ ed., Easton, 1968, pp. 351-369.

12. Partington, J. R.; A History of Chemistry, 4 vols, reimpressão, St. Martin's Press: New York, 2000, vol. 3, p. 213.

13. Ihde, A. J.; The Development of Modern Chemistry, Harper \& Row: New York, 1970, pp. 231-235.

14. Ihde, A. J.; The Development of Modern Chemistry, Harper \& Row: New York, 1970, p. 373

15. Ihde, A. J.; The Development of Modern Chemistry, Harper \& Row: New York, 1970, p. 236.

16. Ihde, A. J.; The Development of Modern Chemistry, Harper \& Row: New York, 1970, pp. 238.

17. https://petiteshistoiresdessciences.wordpress.com/2015/04/17/laclassification-periodique, acessado em junho de 2019.

18. Partington, J. R.; op. cit., vol. 4, p.887.

19. Partington, J. R.; op. cit., p. 888.

20. Partington, J. R.; op. cit., p. 891, diz que, ao assinar o livro de visitas da Royal Society, ele escreveu seu nome como Mendeleeff.

21. Partington, J. R.; op. cit., p. 892.

22. Filgueiras. C. A. L.; Quim. Nova 2002, 25, 1040

23. Cannizzaro, S.; Sunto di um Corso di Filosofia Chimica, Genova, 1858.

24. Meyer, L.; Les Théories Modernes de la Chimie et Leur Application á la Mécanique Chimique, 2 vols., Georges Carré, Paris, 1887-1889.

25. Mendeleev, D. I.; Osnovy Khimii (Princípios de Química), São Petersburgo, 1869.

26. Mendeleev, D.; Zeitschrift für Chemie 1869, 12, 405.

27. Mendeleev, D.; Annalen der Chemie und Pharmazie, VIII Supplementband, Leipzig und Heidelberg, 1872, 133.

28. Partington, J. R.; op. cit., vol. 4., p. 891.

29. Meyer, L.; Annalen der Chemie 1870, Supplement 7, 754.

30. Partington, J. R.; op. cit., vol. 4., p. 895.

31. Meyer, L.; Annalen der Chemie, 1870, Supplement 7, 35.

32. Filgueiras, C. A. L.; Origens da Química no Brasil, Editora da Unicamp: Campinas, 2015, pp. 360-362.

33. Fontani, M., Costa, M., Oma, M. V.; The Lost Elements: The Periodic Table's Shadow Side, Oxford University Press: Oxford, 2014, p. 136.

34. Lecoq de Boisbaudran, P.-É.; Comptes Rendus 1879, LXXXIX, 516.

35. Soret, J.-L.; Comptes Rendus 1879, LXXXIX, 521.

36. Ihde, A. J.; op. cit., p. 369-374.

37. Idem, p. 490.

38. Greenwood, N. N.; Earnshaw, A.; Chemistry of the Elements, Pergamon Press, Oxford, 1986, p. 1047.

39. Cohen, E.; Jacobus Henricus van'Hoff, sein Leben und Wirken, Akademische Verlagsgesellschaft m.b.H, Leipzig, 1912, p. 424.

40 Weeks, M. E.; J. Chem. Educ. 1932, 9, 1751.

41. Emsley, J.; Nature's Building Blocks - an A-Z guide to the elements, OUP: Oxford, 2001, pp. 343-346.

42. Weeks, M. E.; Leicester, H. M.; op. cit., pp. 667-699.

43. Urbain, G.; Chem. Rev. 1924, 1, 143.

44. Souza Filho, P. C., Serra, O. A.; Quim. Nova 2014, 37, 753.

45. Marinsky, J. A., Glendenin, L. E.; Manhattan Project Report CN-2809 (abril 1945) e CC-2829 (junho 1945).

46. Marinsky, J. A., Glendenin, L. E., Coryell, C. D.; J. Am. Chem. Soc. 1947, 69, 2781. Mais tarde o tempo de meia-vida do promécio foi redeterminado como 53,1 horas: Heiserman, D. L.; Exploring Chemical Elements and their Compounds, TAB Books: New York, 1992, p. 223.

47. Gould, R. F.; Chem. Eng. News 1947, 25, 2555.

48. Trifonov, D. N., Trifonov, V. D.; Chemical Elements - How they were discovered, Mir Publishers: Moscow, 1982, p. 126.

49. Brooks, N.; Found. Chem. 2002, 5, 127.
50. Brauner, B.; Z. Anorg. Chem. 1902, 32, 1.

51. Laing, M.; Found. Chem. 2005, 7, 203.

52. Ritter, S. K.; Chem. Eng. News, 2017, 95, 30.

53. Erikson, B.; Chem. Eng. News, 2018, 96, 29.

54. Partington, J. R.; op. cit., vol. 4., p. 938.

55. Emsley, J.; The Elements, Clarendon Press: Oxford, 1991, p. 199.

56. Partington, J. R.; op. cit., vol. 4., p. 951.

57. Emsley, J.; op. cit., pp. 160-161.

58. https://en.wikipedia.org/wiki/Francium, acessado em junho de 2019.

59. Ihde, A. J.; op. cit., pp. 374-379.

60. Ihde, A. J.; op. cit., pp. 590-591.

61. Ihde, A. J.; op. cit., p. 486.

62. Moseley, H. G.; Philos. Mag. 1914, 27, 703.

63. Ihde, A. J.; op. cit., pp. 493-494.

64. Ihde, A. J.; op. cit., p. 509.

65. Ihde, A. J.; op. cit., pp. 517-518.

66. Laboratório fundado em 1931 por Ernest Lawrence, criador do importante equipamento cíclotron. Localiza-se na Universidade da Califórnia em Berkeley, EUA. Ao longo dos anos seus pesquisadores colaboraram direta ou indiretamente com a descoberta de vários elementos químicos transurânicos e superpesados. Doze de seus pesquisadores foram agraciados com o prêmio Nobel em Química ou em Física.

67. L'Annunziata, M. F.; Radioactivity: Introduction and History, Elsevier Science: Amsterdam, 2007, p. 2.

68. Wilson, S. Em Theoretical chemistry and physics of heavy and superheavy elements; Kaldor, U., Wilson, S., eds.; Springer: New York, 2003, cap. 1.

69. Esse instituto de pesquisa iniciou suas atividades em 1956 na ex-União Soviética, dois anos após a criação do CERN.

70. Mcmillan, E; Abelson, P. H.; Phys. Rev. 1940, 57, 1185

71. Emsley, J.; op. cit., pp. 324-329.

72. Seaborg, G. T.; Science 1946, 104, 379.

73. Seaborg, G. T.; US3156523A, 1946

74. Thompson, S.; Ghiorso, A.; Seaborg, G.; Phys. Rev. 1950, 80, 781.

75. Ghiorso, A.; Chem. Eng. News. 2003, 81, 174.

76. Ghiorso, A.; Harvey, B.; Choppin, G.; Thompson, S.; Seaborg, G. T.; Phys. Rev. 1955, 98, 1518

77. Barber, R. C.; Greenwood, N. N.; Hrynkiewicz, A. Z.; Jeannin, Y. P.; Lefort, M.; Sakai, M.; Ulehla, I.; Wapstra, A. P.; Wilkinson, D. H.; Pure Appl. Chem. 1993, 65, 1757.

78. Loss, R. D.; Corish, J.; Pure Appl. Chem. 2012, 84, 1669.

79. Ghiorso, A.; Nitschke, J. M.; Alonso, J. R.; Alonso, C. T.; Nurmia, M.; Seaborg, G. T.; Hulet, E. K.; Lougheed R. W.; Phys. Rev. Lett. 1974, 33, 1490.

80. Utyonkov, V. K.; Brewer, N. T.; Oganessian, Y. T.; Rykaczewski, K. P.; Abdullin, F. S.; Dmitriev, S. N.; Grzywacz, R. K.; Itkis, M. G.; Miernik, K.; Polyakov, A. N.; Roberto, J. B.; Sagaidak, R. N.; Shirokovsky, I. V.; Shumeiko, M. V.; Tsyganov, Y. S.; Voinov, A. A.; Sub-botin, V. G.; Sukhov, A. M.; Karpov, A. V.; Popeko, A. G.; Sabel'nikov, A. V.; Svirikhin, A. I.; Vostokin, G. K.; Hamil-ton, J. H.; Kovrizhnykh, N. D.; Schlattauer, L.; Stoyer, M. A.; Gan, Z.; Huang, W. X.; Ma, L.; Phys. Rev. C 2018, 97, 1.

81. Oganessian, Y. T.; Demin, A. G.; Danilov, N. A.; Flerov, G. N.; Ivanov, M. P.; Iljinov, A. S.; Kolesnikov, N. N.; Markov, B. N.; Plotko, V. M.; Tretyakova, S. P.; Nucl. Phys. A 1976, 273, 505.

82. Münzenberg, G.; Hofmann, S.; Hessberger, F. P.; Reisdorf, W.; Schmidt, K. H.; Schneider, J. H. R.; Armbruster, P.; Sahm, C. C.; Thuma, B.; Z. Phys. A 1981, 300, 107.

83. Ghiorso, A.; Seaborg, G. T.; Oganessian, Y. T.; Zvara, I.; Armbruster, P.; Hessberger, F. P.; Hofmann, S.; Leino, M.; Munzenberg, G.; Reisdorf, W.; Schmidt, K.-H., Pure Appl. Chem. 1993, 65, 1815.

84. Münzenberg, G.; Armbruster, P.; Folger, H.; Heßberger, F. P.; Hofmann, 
S.; Keller, J.; Poppensieker, K.; Reisdorf, W.; Schmidt, K.-H.; Schött, H.-J.; Leino, M. E.; Hingmann, R.; Z. Phys. A 1984, 317, 235.

85. Ninov, V.; Gregorich, K. E.; Loveland, W.; Ghiorso, A.; Hoffman, D. C.; Lee, D. M.; Nitsche, H.; Swiatecki, W. J.; Kirbach, U. W.; Laue, C. A.; Adams, J. L.; Patin, J. B.; Shaughnessy, D. A.; Strellis, D. A.; Wilk, P. A.; Phys. Rev. Lett. 1999, 83, 1104.

86. Münzenberg, G.; Armbruster, P.; Hessberger, F. P.; Hofmann, S.; Poppensieker, K.; Reisdorf, W.; Schneider, J. H. R.; Schneider, W. F. W.; Schmidt, K.-H.; Sahm, C.-C.; Vermeulen, D.; Z. Phys. A 1982, 309, 89.

87. "Names and symbols of transfermium elements (IUPAC Recommendations)", Pure Appl. Chem. 1994, 66, 2419.

88. Hofmann, S; Rep. Prog. Phys. 1998, 61, 639.

89. Hofmann, S.; Ninov, V.; Hessberger, F.P.; Armbruster, P.; Folger, H.; Münzenberg, G.; Schött, H. J.; Popeko, A. G.; Yeremin, A. V.; Andreyev, A. N.; Saro, S.; Janik, R.; Leino, M.; Z. Phys. A 1995, 350, 281.

90. Corish, J.; Rosenblatt, G. M.; Pure Appl. Chem. 2004, 76, 2101.

91. Hofmann, S.; Ninov, V.; Heßberger, F. P.; Armbruster, P.; Folger, H.; Münzenberg, G.; Schött, H. J.; Popeko, A. G.; Yeremin, A. V.; Saro, S.; Janik, R.; Leino M.; Z. Phys. A 1996, 354, 229.

92. Barber, R. C.; Gäggeler, H. W.; Karol, P. J.; Nakahara, H.; Vardaci, E.; Vogt E.; Pure Appl. Chem. 2009, 81, 1331.

93. Morita, K.; Morimoto, K.; Kaji, D.; Akiyama, T.; Goto, S.; Haba, H.; Ideguchi, E.; Kanungo, R.; Katori, K.; Koura, H.; Kudo, H.; Ohnishi, T.; Ozawa, A.; Suda, T.; Sueki, K.; Xu, H.; Yamaguchi, T.; Yoneda, A.; Yoshida, A.; Zhao, Y.; J. Phys. Soc. Jpn. 2004, 73, 2593.

94. Oganessian, Y. T.; Utyonkov, V. K.; Lobanov, Y. V.; Abdullin, E S.; Polyakov, A. N.; Shirokovsky, I. V.; Tsyganov, Y. S.; Gulbekian, G. G.; Bogomolov, S. L.; Gikal, B. N.; Mezentsev, A. N.; Iliev, S.; Subbotin,
V. G.; Sukhov, A. M.; Ivanov, O. V.; Buklanov, G. V.; Subotic, K.; Itkis, M. G.; Moody, K. J.; Wild, J. E.; Stoyer, N. J.; Stoyer, M. A.; Lougheed, R. W.; Phys. Rev. C. 2000, 62, 041604.

95. Oganessian, Y. T.; Utyonkoy, V. K.; Lobanov, Y. V.; Abdullin, F. S.; Polyakov, A. N.; Shirokovsky, I. V.; Tsyganov, Y. S.; Gulbekian, G. G.; Bogomolov, S. L.; Mezentsev, A. N.; Iliev, S.; Subbotin, V. G.; Sukhov, A. M.; Voinov, A. A.; Buklanov, G. V.; Subotic, K.; Zagrebaev, V. I.; Itkis, M. G.; Patin, J. B.; Moody, K. J.; Wild, J. F.; Stoyer, M. A.; Stoyer, N. J.; Shaughnessy, D. A.; Kenneally, J. M.; Lougheed, R. W.; Phys. Rev. C., 2004, 69, 021601.

96. Hulet, E. K.; Lougheed, R. W.; Wild, J. F.; Landrum, J. H.; Stevenson, P. C.; A. Ghiorso; Nitschke, J. M.; Otto, R. J.; Morrissey, D. J.; Baisden, P. A.; Gavin, B. F.; D. Lee; Silva, R. J.; Fowler, M. M.; Seaborg, G. T.; Phys. Rev. Lett. 1977, 39, 385.

97. Oganessian, Y. T.; Abdullin, F. S.; Bailey, P. D.; Benker, D. E.; Bennett, M. E.; Dmitriev, S. N.; Ezold, J. G.; Hamilton, J. H.; Henderson, R. A.; Itkis, M. G.; Lobanov, Y. V.; Mezentsev, A. N.; Moody, K. J.; Nelson, S. L.; Polyakov, A. N.; Porter, C. E.; Ramayya, A. V.; Riley, F. D.; Roberto, J. B.; Ryabinin, M. A.; Rykaczewski, K. P.; Sagaidak, R. N.; Shaughnessy, D. A.; Shirokovsky, I. V.; Stoyer, M. A.; Subbotin, V. G.; R. Sudowe; Sukhov, A. M.; Tsyganov, Y. S.; Utyonkov, V. K.; Voinov, A. A.; Vostokin, G. K.; Wilk, P. A.; Phys. Rev. Lett. 2010, 104, 142502. 98. Grosse, A. V.; J. Inorg. Nucl. Chem. 1964, 26, 1801.

99. Nash, C. S.; J. Phys. Chem. A 2005, 109, 3493.

100. Connely, N. G.; Damhus, T.; Hartshorn, R. M.; Hutton, A. T.; Nomenclatura de Química Inorgânica - Recomendações da IUPAC de 2005, IST Press: Lisboa, 2017. 